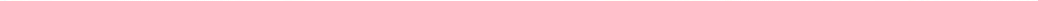




\section{BUKU AJAR \\ ASESMEN MINAT DAN BAKAT \\ TEORI DAN APLIKASINYA}

Oleh Dra. Dwi Nastiti,

M.Si.

Nurfi Laili, S.Psi., M.Psi., Psikolog

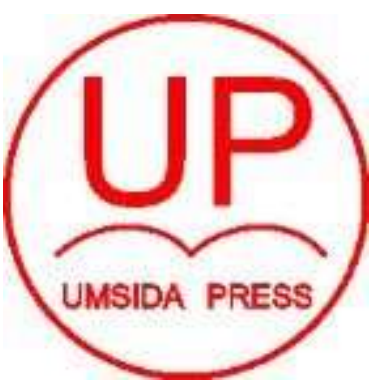

Diterbitkan Oleh : UMSIDA Press

UNIVERSITAS MUHAMMADIYAH SIDOARJO 2020 


\section{BUKU AJAR ASESMEN MINAT DAN BAKAT TEORI DAN APLIKASINYA}

Penulis:

Dra. Dwi Nastiti, M.Si. Nurfi Laili,

S.Psi., M.Psi., Psikolog

ISBN :

978-623-6833 74-2

\section{Editor:}

Effy Wardati Maryam, M.Si.

Design Sampul dan Tata Letak:

Mochammad Nashrullah, S.Pd.

Amy Yoga Prajati, S.Kom.

\section{Penerbit:}

UMSIDA Press

Anggota IKAPI No. 218/ANggota Luar Biasa/JTI/2019

Anggota APPTI No. 0020181092017

\section{Redaksi}

Universitas Muhammadiyah Sidoarjo

Jl. Mojopahit No 666B

Sidoarjo, Jawa Timur

Cetakan Pertama, September 2020

(C) Hak Cipta dilindungi undang undang 
Dilarang memperbanyak karya tulis ini dengan sengaja, tanpa ijin tertulis dari penerbit.

\section{KATA PENGANTAR}

Puji syukur kami panjatkan ke hadirat Allah SWT atas rahmat dan karunia Nya buku ajar Asesmen Minat dan Bakat dapat diselesaikan dengan baik dan tanpa halangan yang berarti. Shalawat dan salam selalu kami sampaikan kepada junjungan Nabi Muhammad SAW.

Tim penulis mengucapakan terima kasih kepada :

1. Dr. Akhtim Wahyuni, M.Ag., selaku Dekan Fakultas Psikologi dan Ilmu Pendidikan yang telah memberi arahan dan motivasi kepada penulis dalam menyelesaikan buku ajar ini

2. Widyastuti, M.Psi., Psikolog., selaku Kaprodi Psikologi yang telah memberi dukungan untuk menyusun buku ajar ini

3. Seluruh rekan-rekan dosen pengampu di prodi Psikologi yang telah berbagi pengetahuan dalam penyusunan buku ajar ini.

Saran dan kritik sangat penulis harapkan untuk mewujudkan buku ajar asesmen minat dan bakat yang lebih baik, dan sesuai dengan peraturan yang berlaku. Terima kasih. 


\section{DAFTAR ISI}

HALAMAN SAMPUL

al

KATA PENGANTAR

DAFTAR ISI

BAB I: Pendahuluan
A. Pengantar
B. Sejarah Psikodiagnostik
C. Pengertian Psikodiagnostik
D. Kedudukan psikodiagnostik
E. Tujuan Psikodiagnostik
F. Psikodiagnostik dan Tes Minat-Bakat
G. Ringkasan

H. Latihan soal

I. Referensi

BAB II : Konsep Minat dan Bakat
A. Pengantar

B. Minat

C. Bakat 
D. Ringkasan

E. Latihan Soal

F. Referensi

BAB III : Tes Minat
A. Pengantar

B. Macam-macam Tes Minat

C. Ringkasan

D. Latihan Soal

E. Tugas

F. Referensi

BAB IV : Tes Bakat :

A. Pengantar

B. Macam-macam Tes Bakat

C. Ringkasan 
D. Latihan Soal

E. Tugas

F. Referensi

BAB V : Aplikasi tes minat \& tes

bakat

A. Pengantar

1. Aplikasi Tes MInat

0

2. Aplikasi Tes Bakat

4

C. Ringkasan

D. Latihan Soal

01

E. Tugas

01

F. Referensi

02

DAFTAR PUSTAKA

BIODATA PENULIS 
BATANG TUBUH DAN CAPAIAN PEMBELAJARAN MATA KULIAH

\begin{tabular}{|c|c|}
\hline BAB & Sub-Capaian Pembelajaran Mata Kuliah \\
\hline $\begin{array}{l}\text { BAB I } \\
\text { Pendahuluan }\end{array}$ & $\begin{array}{l}\text { 1. Mahasiswa mampu memahami dan menjelaskan } \\
\text { sejarah, pengertian, tujuan psikodiagnostik, serta } \\
\text { kedudukan tes minat dan tes bakat }\end{array}$ \\
\hline $\begin{array}{l}\text { BAB II } \\
\text { Konsep Minat dan Bakat }\end{array}$ & $\begin{array}{l}\text { 1. Mahasiswa mampu menjelaskan tentangpengertian } \\
\text { minat \& bakat } \\
\text { 2. Mahasiswa mampu menjelaskan konsep } \\
\text { tentangminat dan bakat, serta perbedaan minat } \\
\text { dan bakat }\end{array}$ \\
\hline $\begin{array}{l}\text { BAB III } \\
\text { Tes Minat }\end{array}$ & $\begin{array}{l}\text { 1. Mahasiswa mampu mengidentifikasi masing-masing } \\
\text { macam tes minat, yaitu Kuder, } \\
\text { RMIB, Holland test (SDS), dll. }\end{array}$ \\
\hline $\begin{array}{l}\text { BAB IV } \\
\text { Tes Bakat }\end{array}$ & $\begin{array}{l}\text { 1. Mahasiswa mampu mengidentifikasi masing- } \\
\text { masing macam tes bakat kelompok, yaitu : DAT, } \\
\text { GATB, FACT } \\
\text { 2. Mahasiswa mampu mengidentifikasi masing- } \\
\text { masing macam tes bakat tunggal, yaitu : kraepelin, } \\
\text { dll. }\end{array}$ \\
\hline $\begin{array}{l}\text { BAB V } \\
\text { Aplikasi tes minat \& tes } \\
\text { bakat }\end{array}$ & $\begin{array}{l}\text { 1. Mahasiswa mampu menerapkan tes minat di } \\
\text { bidang pendidikan, pekerjaan, penelitian } \\
\text { 2. Mahasiswa mampu menerapkan tes bakat di } \\
\text { bidang pendidikan, pekerjaan, penelitian }\end{array}$ \\
\hline
\end{tabular}




\section{BAB I PENDAHULUAN}

\section{Kemampuan Akhir Yang Direncanakan :}

Setelah mempelajari bab ini, diharapkan mahasiswa mampu memahami dan menjelaskan sejarah, pengertian, tujuan psikodiagnostik, serta kedudukan tes minat dan tes bakat

\section{A. PENGANTAR}

Psikologi adalah ilmu yang mempelajari tentang perilaku manusia. Dalam usaha memahami perilaku manusia diperlukan alat yang tepat, yang bisa menggambarkan keseluruhan potensi yang dimiliki manusia, bahkan setiap manusia mengingat adanya individual differences. Psikodiagnostik adalah jawaban untuk bisa memahami perilaku manusia. Untuk itulah psikodiagnostik tidak pernah lepas di setiap kegiatan pengukuran di bidang psikologi, baik untuk kebutuhan teoritis maupun kebutuhan praktis.

Psikodiagnostik muncul karena kebutuhan untuk mendapatkan data psikologis yang tepat yang digunakan untuk memberi keputusan atau saran berkaitan dengan potensi yang dimiliki manusia.

Psikodiagnnostik dipengaruhi oleh perkembangan dalam psikometri dan oleh pertumbuhan pengetahuan pada subdisiplin/cabang ilmu psikologi. Psikodiagnostik bukanlah sub-disiplin dari psikologi, seperti psikologi sosial, psikologi klinis, psikologi perkembangan dan subdisiplin lainnya. Psikodiagnostik menjadi bagian dari psikologi dan terikat dengan metode untuk asesmen perbedaan individual dalam perilaku, termasuk sebagai alat dalam melakukan proses identifikasi dalam permasalahan psikologis. 
Pada awalnya pemeriksaan psikologi (asesmen psikologis) digunakan untuk memecahkan persoalan-persoalan praktis, baik pada individu, kelompok, institusi atau bidang-bidang sosial.

Psikodiagnostik ini muncul dilatarbelakangi oleh kebutuhan klinis. Dalam perkembangannya kebutuhan, untuk membuat diagnosis secara psikologis, tidak saja dalam lapangan klinis, sehingga perkembangan psikodiagnostik semakin luas. Psikodiagnostik sering disamakan dengan asesmen, tetapi psikodiagnostik lebih dari sekedar asesmen. Psikodiagnostik didalamnya mengandung judgment atau advice.

Selanjutnya akan dibahas secara lebih detil hal-hal yang berkaitan dengan psikodiagnostik, seperti sejarah psikodiagnostik, pengertian psikodiagnostik, kedudukan psikodiagnostik, tujuan psikodiagnostik, dan apa kaitannya dengan tes minat dan bakat.

\section{B. SEJARAH PSIKODIAGNOSTIK}

Penggunaan istilah psikodiagnostik secara eksplisit muncul ketika Hermann Rorschach menerbitkan hasil penelitian dengan metode Rorschach dalam lapangan psikiatri dengan judul psikodiagnostik (Marnat, 2009).

Marcham S.S (1990) mencoba memberikan gambaran secara detil sejarah perkembangan tes psikologi, yang menjadi cikal bakal munculnya psikodiagnostik, yang secara eksplisit baru dikemukakan oleh Rorschach pada tahun 1921.

Tabel I.1. Sejarah Psikodiagnostik 


\begin{tabular}{|c|c|}
\hline Yunani Kuno & $\begin{array}{l}\text { Mulai mengadakan tes untuk evaluasi proses pendidikan } \\
\text { Kerajaan Yunani Kuno. }\end{array}$ \\
\hline $\begin{array}{l}\text { Abad } \\
\text { Pertengahan }\end{array}$ & $\begin{array}{l}\text { Penggunaan test untuk pendidikan formal di Universitas : - } \\
\text { Huarts (abad 16), salah satu perintis Psikodiagnostik Spanyol } \\
\text { yang mencoba memilah anak berbakat. } \\
\text { - Gall (1758-1822), (a) mengukur tengkorak atau prheno-logy } \\
\text { untuk mengukur tingkat kepandaian seseorang; (b) } \\
\text { berpikiran mengenai kemungkinan mengukur intelegensi. }\end{array}$ \\
\hline 1837 & $\begin{array}{l}\text { Seguin: (a) mempelopori pemberian pelatihan bagi penderita } \\
\text { retardasi mental; (b) memperhatikan unsur motorik, yang } \\
\text { dalam perkembangannya mengarah pada tes inteligensi non } \\
\text { verbal }\end{array}$ \\
\hline 1838 & $\begin{array}{l}\text { Publikasi Mental Retardation (MR) oleh Esquirol termasuk } \\
\text { di dalam nya membahas jenis serta level gangguannya }\end{array}$ \\
\hline 1884 & $\begin{array}{l}\text { Francis Galton yang pertama kali mengembangkan tes } \\
\text { dengan tujuan utama practical problem; dan } \\
\text { meng-administrasikan test battery pertama }\end{array}$ \\
\hline 1879 & $\begin{array}{l}\text { riset psikologis di Universitas Leipzig, berupaya me-mahami } \\
\text { pikiran manusia dengan mengidentifikasi elemen pembentuk } \\
\text { kesadaran manusia }\end{array}$ \\
\hline 1890 & $\begin{array}{l}\text { James McKeen Cattell menggunakan menemukan tes mental } \\
\text { pertama, hampir sama dengan yang dikemukakan Galton }\end{array}$ \\
\hline 1897 & $\begin{array}{l}\text { Usaha pengembangan tes-tes seperti aritmatik, memory } \\
\text { span, dan sentence completion yang dilakukan Ebbinghaus. }\end{array}$ \\
\hline 1901 & $\begin{array}{l}\text { Clark Wissler membuktikan bahwa tidak ada korelasi Brass } \\
\text { Instrument dengan nilai akademik seseorang }\end{array}$ \\
\hline 1905 & $\begin{array}{l}\text { Binet dan Simon mengembangkan penggunaan tes } \\
\text { intelegensi modern yang berfungsi mengidentifikasikan } \\
\text { kemampuan sekolah anak. }\end{array}$ \\
\hline 1913 & $\begin{array}{l}\text { Pembuatan Alat tes Army Alpha \& Army Beta oleh Robert } \\
\text { Yerkes dimaksudkan untuk penerimaan sukarelawan PD I. }\end{array}$ \\
\hline 1916 & $\begin{array}{l}\text { Revisi alat tes Binet dan Simon oleh Lewis Terman sehingga } \\
\text { terbentuk tes Stanford dan Binet }\end{array}$ \\
\hline
\end{tabular}




\begin{tabular}{ll}
\hline 1917 & $\begin{array}{l}\text { Pertama kalinya dibuat instrumen kepribadian oleh Robert } \\
\text { Woodworth dalam bentuk Personal Data Sheet. }\end{array}$ \\
\hline 1920 & $\begin{array}{l}\text { Herman Rorschach untuk pertama kalinya menggunakan } \\
\text { istilah PSIKODIAGNOSTIK, setelah melakukan eksperimen } \\
\text { menggunakan bercak-bercak tinta dalam rangka mengukur } \\
\text { kepribadian. }\end{array}$ \\
\hline 1921 & $\begin{array}{l}\text { Psychological Corporation, peneliti utama dari alat-alat tes } \\
\text { psikologi didirikan oleh Cattell, Thorndike dan Woodworth }\end{array}$ \\
\hline 1925 & $\begin{array}{l}\text { Berkembangnya SAT (Scholastic Aptitude Test) oleh Bingham } \\
\text { dan teman-temannya dan dikembangkan kembali oleh } \\
\text { Spearman, Thurstone, Kelly }\end{array}$ \\
\hline 1927 & Edisi Pertama Strong Vocational Interest Blank diterbitkan \\
\hline 1939 & Weschler Bellevue Intelegence Scale diterbitkan \\
\hline 1942 & Minnesota Multiphasic Personality Inventory diterbitkan \\
\hline
\end{tabular}

Pada awalnya, istilah psikodiagnostik sering digunakan untuk menetapkan kelainan-kelainan psikologis pasien sehingga bisa dilakukan treatmen atau pemberian pengobatan sesuai dengan kelainan yang diderita pasien klinis. Kemudian ilmu psikologi berkembang, sehingga berkembang pula penggunaan istilah psikodiagnostik di hampir semua bidang kegiatan dimana manusia berada, seperti di bidang sosial, organisasi dan industri, pendidikan, juga bidang perkembangan.

\section{PENGERTIAN PSIKODIAGNOSTIK}

Dalam rangka mengerti apa itu psikodiagnostik kita akan menemukan banyak pengertian tentang psikodiagnostik. Dilihat dari asal katanya, Psikodiagnostik berasal dari 2 kata, yaitu : psikologi dan diagnostik. Psikologi adalah ilmu tentang tingkah laku manusia, sedangkan diagnostik adalah mencari tahu. Dengan demikian, bila 
dilihat dari asal kata, psikodiagnostik berarti ilmu yang berkaitan dengan mencari tahu tentang masalah perilaku yang muncul.

Secara Teoritis, Psikodiagnostik adalah studi ilmiah tentang berbagai metode membuat diagnosis psikologis, dengan tujuan : dapat memperlakukan manusia dengan lebih tepat. Secara Praktis, Psikodiagnostik adalah setiap metode untuk membuat diagnosis psikologis, dengan tujuan agar dapat memperlakukan manusia dengan lebih tepat (Suryabrata, 2005).

Bila diartikan secara sempit, psikodiagnostik adalah metode yang digunakan untuk menetapkan kelainan-kelainan psikis, dengan tujuan untuk dapat memberikaan pertolongan secara tepat. HIMPSI sendiri memberi pengertian luas tentang psikodiagnostik yaitu salah satu bentuk pemeriksaan psikologis yang dilakukan dengan teknik-2 dan alat ukur tertentu yang telah distandardisir guna menemukan sifat-sifat yang melandasi perilaku atau kepribadian tertentu. Diagnostik sendiri, secara luas bisa diartikan sebagai seperangkat alat ukur yang dimaksudkan untuk mendapat informasi tentang pikiran, perasaan, persepsi, dan perilaku seseorang, yang digunakan untuk membuat keputusan diagnostik tentang orang tersebut (Himpsi, 2000)

Dalam pengertian psikodiagnostik sebenarnya mengandung unsur pemeriksaan psikologis dengan menggunakan teknik dan alat ukur yang telah distandardisir. Pemeriksaan Psikologis adalah pemeriksaan pada aspek-aspek psikologis diri subyek yang hendak diperiksa untuk suatu maksud atau tujuan tertentu. Sedangkan, teknik dan alat ukur yang telah terstandardisir dikembangkan di bidang psikologi berupa tes psikologi, selain wawancara dan observasi. Hal yang harus menjadi perhatian betul jika melakukan pemeriksaan psikologis adalah tidak membedakan perlakuan siapapun individu yang dihadapi. 
Pengertian psikodiagnostik sering disamakan dengan asesmen atau tes. Psikodiagnostik lebih dari sekedar asesmen maupun tes. Asessmen adalah alat ukur yang digunakan untuk mengumpulkan dan mengintegrasi informasi yang akan digunakan untuk evaluasi kondisi psikologis (guna mengenali dan menyelesaikan masalah menjadi lebih efektif). Test Psikologi adalah alat ukur yang digunakan untuk mengetahui variabel-variabel psikologi (berupa pertanyaanpertanyaan yang harus dijawab dan atau perintah-perintah yang harus dijalankan)

Pengertian terakhir dari psikodiagnostik dikaitkan dengan usaha untuk pemeriksaan, yaitu mengartikan Psikodiagnostik sebagai cara untuk menegakkan diagnosa Informasi yang ada harus diintegrasikan dalam suatu judgment atau advice. Pengertian ini yang menunjukkan bahwa psikodiagnostik lebih dari suatu asesmen atau suatu tes.

\section{KEDUDUKAN PSIKODIAGNOSTIK}

Sejak awal psikodiagnostik adalah bagian dari psikologi dan terikat dengan metode untuk asesmen perbedaan individual dalam berperilaku, bukan sebagai subdisiplin psikologi. Bentuk-bentuk metodenya : observasi, wawancara, dan tes.

Seperti dijelaskan di atas, pada awalnya psikodiagnostik ini lebih sering digunakan dalam bidang klinis, tetapi kemudian, dengan berkembangnya ilmu psikologi, penggunaan psikodiagnostik meluas ke bidang pendidikan, organisasi dan industri, sosial dan perkembangan, dan bidang lain.

Penggunaan psikodiagnostik ada di beberapa bidang :

1. Bidang Klinis

Di bidang ini, psikodiagnostik digunakan untuk mengetahui apakah ditemukan indikasi yang mengarah pada adanya kelainan 
psikis pada individu atau klien, sekaligus untuk mengetahui potensi pribadi klien yang mungkin bisa diandalkan individu atau klien, sehingga dapat diketahui terapi atau treatment yang efektif untuk mengatasi gangguan psikis individu. Asesmen ini bisa ditemui di tempat-tempat seperti Rumah Sakit, pusat kesehatan mental, atau tempat konsultasi psikologi menerapkan proses psikodiagnostik ini.

\section{Bidang Perkembangan}

Bidang ini memanfaatkan proses psikodiagnostik di berbagai usia, misal: penggunaan metode dalam psikodiagnostik untuk mengetahui kemungkinan hambatan perkembangan anak, gangguan emosi remaja, dan sebagainya. Sekolah, Layanan konseling, atau Pusat Konsultasi Psikologi merupakan tempat-tempat dimana proses psikodiagnostik ini diterapkan.

\section{Bidang Pendidikan}

Fokus pemeriksaan psikodiagnostik di di bidang ini lebih ditekankan untuk bidang evaluasi belajar, pengembangan minat dan bakat. Penerapan pengukuran potensi bakat seseorang sering dilakukan di bidang pendidikan, yaitu untuk tujuan Penjurusan, penentuan Ekstrakurikuler, dan Konseling di sekolah, di universitas, di tempat pelatihan atau di tempat pemberian bimbingan karir memanfaatkan proses psikodiagnostik. Proses penjurusan di SMA atau pemilihan program studi di Perguruan Tinggi, juga pemilihan pekerjaan adalah kegiatan yang memanfaatkan proses psikodiagnostik.

\section{Bidang Industri dan Organisasi}

Psiodiagnostik di bidang ini digunakan untuk rekrutmen di perusahaan dan bidang pekerjaan, saat melaksanakan seleksi, penempatan, evaluasi kerja, mutasi, dll.

5. Bidang Penelitian dan Terapan 
Psikodiagnostik juga dimanfaatkan sebagai upaya pengembangan ilmu psikologi, juga untuk pengembangan teknik serta metode diagnostik yang sudah ada. Kegiatan seperti ini digunakan di ruang lingkup akademik dan perguruan tinggi.

Di bidang terapan, salah satunya adalah bidang hukum. Bidang hukum memanfaatkan proses psikodiagnostik sebagai usaha mendukung sepenuhnya proses peradilan seperti mengungkap kondisi psikologis seseorang yang bisa digunakan untuk menentukan apakah seseorang bisa dinyatakan bersalah atau tidak, atau harus mengikuti proses rehabilitasi. Peradilan, Lembaga Pemasyarakatan, atau Pusat Rehabilitasi merupakan tempat-tempat dimana proses psikodiagnostik diterapkan.

\section{E. TUJUAN PSIKODIAGNOSTIK}

Ada beberapa tujuan pemanfaatan psikodiagnostik :

1. Untuk mengetahui adanya perbedaan-perbedaan individu. De Zeeuw (1984) menyatakan bahwa psikodiagnotik ditujukan untuk asesmen perbedaan individual.

2. Untuk mengetahui potensi individu, dan memperlakukan individu sesuai dengan potensi yang dimiliki. Psikodiagnostik membantu kita agar bisa memahami individu secara lebih baik dengan menerapkan teknik wawancara, observasi, atau pemberian tes psikologi.

3. Untuk menetapkan kelainan-kelainan psikis yang dialami individu, seperti menetapkan klien mengalami gangguan skizoferenia, paranoid, dll. 
4. Untuk memberi penanganan yang tepat sesuai dengan kelainan psikologis yang dialami individu, seperti pemberian terapi atau treatment yang efektif untuk mengatasi gangguan psikis individu. 5. Dalam kehidupan sehari-hari, bisa digunakan untuk tujuan mendapatkan problem solving. Pemeriksaan psikodiagnostik akan membantu individu mengenali potensi diri dan memanfaatkan potensinya untuk mengetahui problem solving. F.

\section{PSIKODIAGNOSTIK DAN TES MINAT-BAKAT}

Psikodiagnostik adalah bagian dari psikologi dan terikat dengan metode untuk asesmen perbedaan individual. Bentuk-metode asesmennya antara lain adalah penggunaan tes psikologi. Tes psikologi merupakan serangkaian kegiatan pengukuran untuk mendeskripsikan seseorang, baik kemampuan (ability), kepribadian, kecenderungan dan sebagainya.

Tes psikologi mempunyai fungsi sebagai berikut:

\section{Fungsi Seleksi}

untuk memilih individu-individu yang cocok/sesuai dengan kualifikasi yang diharapkan.. misalnya tes masuk suatu lembaga pendidikan atau tes seleksi jabatan tertentu.

2. Fungsi Klasifikasi

untuk mengelompokkan siswa ke dalam program kelas khusus tertentu.

3. Fungsi Deskripsi

untuk menjelaskan profil seseorang, baik kepribadian, tingkah laku, kemampuan, minat dan bakat dan sebagainya.

4. Mengevaluasi hasil treatment

untuk mengavaluasi suatu treatment/tindakan yang telah dilakukan terhadap seseorang atau sekelompok individu, sampai dimana tingkat keberhasilan treatment yang sudah diberikan.

5. Menguji Hipotesis 
untuk menguji sebuah hipotesis dan asumsi yang ada. Contoh menggunakan tes psikologi yang sudah terstandardisir untuk menentukan keberhasilan suatu eksperimen.

Penggunaan tes minat dan tes bakat merupakan salah satu bentuk penerapan metode psikodiagnostik di bidang pendidikan yang digunakan untuk mengetahui potensi individu, agar bisa memaksimal potensi yang dimiliki individu. Salah satu penerapan metode tes psikologi di lingkungan pendidikan adalah Penelusuran Bakat dan Minat.

Kegiatan ini dilakukan untuk membantu siswa:

1. Memilih sekolah lanjutan atas di SMA atau SMK

Tes ini diberikan kepada siswa kelas 3 SMP yang ingin menentukan jurusan di sekolah lanjutan atas. 2. Memilih program jurusan di SMA

Tes ini diberikan kepada siswa SMA yang ingin menentukan pilihan jurusan IPA/IPS/Bahasa

3. Memilih program studi di Perguruan Tinggi

Tes ini diberikan kepada siswa SMA yang ingin melanjutkan studi di Perguruan Tinggi, sehingga lebih disarankan untuk siswa kelas 11 atau 12.

4. Penyesuaian program studi di Perguruan Tinggi

Tes ini diberikan kepada mahasiswa semester 1-4 yang kurang yakin akan pilihan program studinya dan ingin menelusuri bidang yang lebih sesuai. Asesmen bakat minat akan membantu pemilihan prodi sesuai dengan bakat dan potensi mahasiswa.

5. Memilih program studi ke Luar Negeri

Tes ini diberikan kepada siswa SMA yang ingin melanjutkan studi ke luar negeri. Oleh karena itu lebih disarankan untuk siswa SMA kelas 10 atau 11. 


\section{G. RINGKASAN}

Penggunaan istilah psikodiagnostik secara eksplisit muncul ketika Hermann Rorschach menerbitkan hasil penelitian dengan metode Rorschach dalam lapangan psikiatri dengan judul psikodiagnostik. Pada awalnya, istilah psikodiagnostik sering digunakan untuk menetapkan kelainan-kelainan psikologis pasien klinis, tetapi dengan berkembangnya ilmu psikologi, maka istilah psikodiagnostik meluas ke bidang terapan lain seperti pendidikan, organisasi dan industri, sosial dan perkembangan.

Pengertian psikodiagnostik sering disamakan dengan asesmen atau tes. Psikodiagnostik lebih dari sekedar asesmen maupun tes.

Psikodiagnostik adalah cara untuk menegakkan diagnosa Informasi yang ada harus diintegrasikan dalam suatu judgment atau advice.

Sejak awal psikodiagnostik merupakan bagian dari psikologi terikat dengan metode untuk asesmen perbedaan individual dalam perilaku bukan sebagai subdisiplin psikologi. Bentuk-bentuk metodenya : observasi, wawancara, tes psikologi.

Psikodiagnostik biasanya dimanfaatkan untuk tujuan seperti mengetahui adanya perbedaan-perbedaan individu, me-ngetahui potensi individu, dan memperlakukan individu sesuai dengan potensi yang dimiliki, menetapkan kelainan-kelainan psikis yang dialami individu, dasar pemberian penanganan yang tepat sesuai dengan kelainan psikologis yang dialami individu, atau untuk tujuan mendapatkan problem solving berdasar pemahaman potensi individu lewat pemeriksaan psikodiagnostik.

Penggunaan tes minat dan tes bakat adalah salah satu bentuk penerapan proses psikodiagnostik di bidang pendidikan yang 
digunakan untuk mengetahui potensi individu, agar bisa memaksimal potensi yang dimiliki individu.

Salah satu penerapan metode tes psikologi di lingkungan pendidikan adalah Penelusuran Bakat dan Minat, yang membantu siswa memilih sekolah lanjutan atas di SMA atau SMK, memilih program jurusan di SMA, memilih program studi di Perguruan Tinggi, melakukan penyesuaian program studi di Perguruan Tinggi, atau memilih program studi ke Luar Negeri.

\section{H. LATIHAN SOAL}

1. Buat kesimpulan pengertian psikodiagnostik dari beberapa pengertian yang ada.

2. Jelaskan posisi atau kedudukan psikodiagnostik didalam bidang psikologi.

3. Jelaskan untuk apa saja kita bisa menggunakan pemeriksaan psikodiagnostik

4. Jelaskan penggunaan psikodiagnostik di bidang pendidikan.

\section{REFERENSI}

HIMPSI, 2000. Materi Penyegaran Psikodiagnostik.

Markam,S.S.(1990). Pengantar Psikodiagnostik. Lembaga

Pengembangan Sarana Pengukuran Dan Pendidikan Psikologi.

Fakultas Psikologi Universitas Indonesia, Jakarta.

Marnat, G.G., 2009. Handbook of Psychological Assessment. Fifth Edition. Alih bahasa : Drs. Helly P.P, MA. \& Dra. Sri Mulyantini S., 2010. Cetakan I. Pustaka Pelajar, Yogyakarta. 
Suryabrata, S (2005). Pembimbing ke Psikodiagnostika.

\section{BAB II KONSEP MINAT DAN BAKAT}

\section{Kemampuan Akhir Yang Direncanakan :}

1. Mahasiswa mampu menjelaskan tentang pengertian minat \& bakat

2. Mahasiswa mampu menjelaskan konsep tentang minat dan bakat, serta perbedaan minat dan bakat

\section{A. PENGANTAR}

Perilaku manusia selalu dimotivasi oleh potensi yang dimiliki. Kenyataannya banyak potensi yang dimiliki manusia, dan potensi yang dimiliki setiap manusia berbeda-beda. Selain inteligensi, minat dan bakat menjadi potensi manusia yang juga penting untuk diketahui.

Hal ini yang mendorong munculnya keinginan untuk bisa memahami potensi-potensi yang dimiliki manusia, dan dilanjutkan dengan usaha untuk membuat instrumen yang bisa membantu mengetahui secara tepat ada tidaknya potensi tertentu, dan seberapa besar potensinya. Termasuk didalamnya usaha memahami dan membuat instrumen potensi minat dan bakat manusia. Dalam sejarah psikodiagnostik, baru tahun 1925 berkembang instrumen untuk mengukur potensi bakat yaitu SAT (Scholastic Aptitude Test). Tes ini awalnya disusun oleh Bingham dan kawan kawan.

Selanjutnya, Spearman, Thurstone, Kelly mengembangkan kembali SAT yang disusun Bingham. Sedangkan, instrumen untuk mengukur potensi minat manusia diterbitkan pertama kali, Strong Vocational Interest Blank. Edisi Pertama SVIB diterbitkan pada tahun 1927. 
Di awal muncul pengukuran potensi pertama kali adalah pengukuran potensi fungsi intelektual dengan melakukan tes inteligensi. Dari tes inteligensi diperoleh skor IQ / Taraf Intelektual yaitu kemampuan seseorang untuk menalar, memecahkan masalah, belajar, memahami gagasan, berpikir, dan merencanakan sesuatu. Ternyata, potensi inteligensi dianggap belum cukup mampu memahami keadaan seseorang. Kenyataannya, orang dengan IQ yang sama tidak menunjukkan prestasi yang sama. Potensi bakat dan minat yang dimiliki seseorang akan memberi pemahaman lebih mengapa dan bagaimana seseorang melakukan sesuatu.

Bakat akan sulit berkembang dengan baik apabila tidak diawali dengan adanya minat akan hal yang berkaitan dengan bidang yang akan ditekuni. Minat dianggap sebagai salah satu faktor yang dapat mengarahkan bakat seseorang. Bakat seni, misal, akan berkembang maksimal bila seseorang memiliki minat pada hal-hal yang berkaitan dengan seni. Minat, salah satunya dipengaruhi oleh faktor rasa senang.

Selanjutnya akan dibahas secara lebih mendalam konsep tentang bakat dan minat, termasuk didalamnya pengertian, faktor yang mempengaruhi pemunculan bakat dan minat.

\section{B. MINAT}

Menurut KBBI minat berarti :(a) Menuju pada perhatian; (b) Adanya keinginan untuk memperhatikan; (c) Kemauan untuk melakukan sesuatu; (d) Berminat; (e) ada ketertarikan; (f) ada rasa suka; (g) ada kemauan; (h) ingin akan.

Aiken (1994) menyebut minat sebagai kesukaan terhadap kegiatan melebihi kegiatan lainnya. Ini berarti minat berhubungan dengan nilai nilai yang membuat seseorang mempunyai pilihan dalam hidupnya (Anastasia dan Urbina, 1997). Minat adalah 
kecenderungan terhadap sesuatu, atau dorongan kuat dalam diri seseorang untuk melakukan segala sesuatu yang diinginkan.

Menurut Sandjaja, minat merupakan suatu kecende-rungan yang menyebabkan seseorang berusaha untuk mencari ataupun mencoba aktivitas-aktivitas dalam bidang tertentu. Minat juga diartikan sebagai sikap positif terhadap aspek-aspek lingkungan. Selain itu, minat juga merupakan kecenderungan yang tetap untuk memperhati-kan dan menikmati suatu aktivitas disertai dengan rasa senang. Hal ini berarti minat berkaitan dengan proses seseorang menunjukkan perhatian dan fokus pada hal yang diminati, yang dilakukan secara terus menerus disertai perasaan senang dan memunculkan rasa puas (Ikbal, 2011).

Holland (1997), memberi pengertian minat sebagai suatu kegiatan atau hal-hal yang membangkitkan rasa ingin tahu, kemudian membuat seseorang memberi perhatian, dan memunculkan rasa senang atau nikmat pada diri seseorang. Minat merupakan indikator adanya kekuatan dalam diri seseorang pada bidang kegiatan tertentu yang membuat seseorang termotivasi untuk mempelajarinya dan akan menghasilkan sesuatu secara maksimal.

Guilford (1956) menjelaskan jenis-jenis minat, meliputi :

1. Minat vokasional, yang berkaitan dengan bidang-bidang pekerjaan, seperti :

a) Minat profesional, seperti : minat di bidang keilmuan, bidang kesenian, atau bidang yang berhubungan dengan bidang kesejahteraan sosial.

b) Minat komersial, seperti : minat di bidang usaha 
(wirausaha),bidang pekerjaan yang berurusan dengan jual-beli, pekerjaan di bidang periklanan, pekerjaan yang berhubungan dengan akuntansi, atau bidang kesekretariatan, dan lain-lain.

c) Minat di bidang yang berhubungan dengankegiatan fisik, mekanik, kegiatan luar, dan lain-lain.

2. Minat avokasional, berupa minat untuk memperoleh ke-puasan atau melakukan aktivitas sesuai hobi, misalnya: kegiatan berpetualang, hiburan, apresiasi, atau minat pada pekerjaan yang membutuhkan ketelitian, dan lain-lain. (Suryabrata, 1999)

Minat menjadi potensi yang penting akan memotivasi seseorang untuk mempelajari sesuatu yang disukai dan menjadi pusat perhatiannya dan menunjukkan kinerja yang tinggi. Oleh karena itu harus dilakukan asesmen untuk mengetahui minat seseorang. Hal ini akan dibahas di bab selanjutnya.

\section{BAKAT}

Bakat dalam bahasa Inggris : "aptitude" atau "talent". Bakat merupakan kemampuan yang memang sudah dimiliki oleh setiap orang yang digunakan untuk mempelajari sesuatu dengan cepat, bahkan beberapa diantaranya dalam waktu yang singkat serta memiliki hasil yang sangat baik pula. Bakat memang sudah dimiliki setiap manusia saat dia lahir ke dunia ini.

Dalam arti luas, bakat adalah suatu kapasitas yang dimiliki seseorang untuk mengetahui dan menguasai suatu pengetahuan khusus (dengan latihan), ketrampilan atau serangkaian respon yang terorganisisir. Dengan demikian, bakat atau aptitude dapat diartikan sebagai sebuah kemam-puan bawaan dari seseorang. Kemampuan ini masih berupa potensi yang perlu untuk dikembangkan lebih lanjut dan dilatih agar dapat mencapai impian yang ingin diwujudkan, misal 
kemampuan seseorang di bidang musik, di bidang mekanik, atau kemampuan bahasa.

Bakat dianggap sebagai salah satu wujud dari kemampuan manusia yang sangat menonjol dibandingkan kemampuankemampuan lainnya. Ada beberapa faktor yang dapat mempengaruhi perkembangan bakat yang dimiliki oleh seseorang, antara lain :

1. Tingkat pendidikan yang dilalui

2. Lingkungan sekitar

3. Struktur syaraf serta motorik

4. Motivasi

5. Minat

6. Emosi

7. Kematangan fisik

8. Biologis

9. Peningkatan kualitas ketrampilan fisik

Aktualisasi bakat seseorang tidak akan maksimal jika tidak ditunjang oleh faktor-faktor seperti minat, pengetahuan, pengalaman, atau latihan, dan faktor-faktor lain seperti disebutkan di atas. Dengan demikian, bakat akan tetap hanya merupakan potensi dalam diri seseorang yang tidak akan terwujud tanpa ditunjang faktor-faktor tersebut.

Coba kita lihat bagaimana pengaruh faktor di atas terhadap bakat yang dimiliki seseorang. Jika ada 2 orang mendapat latihan yang sama dalam hal musik, maka seseorang yang memiliki bakat musik akan lebih cepat menguasai ke-trampilan bermusik dibandingkan dengan orang lain yang tidak memiliki bakat musik. 
Dengan demikian sifat bakat yang mendasar adalah bersifat bawaan. Bakat adalah sesuatu yang harus dilatih, dan bakat harus ditunjang dengan minat agar berkembang maksimal.

Dilihat dari cara berfungsinya, bisa kita bedakan 2 jenis bakat yaitu :

\section{Bakat umum}

Potensi dasar yang sifatnya umum. Hal ini bisa berarti, semua orang memang memiliki kemampuan-kemampuan itu. Kemampuan pada bidang khusus (talent), misalnya bakat musik, melukis, dll.

\section{Bakat khusus}

Kemampuan yang dibutuhkan sebagai perantara untuk merealisir kemampuan khusus misalnya bakat melihat ruang 3 dimensi dibutuhkan untuk merealisasi kemampuan di bidang teknik arsitek.

Bakat baru akan muncul bila ada kesempatan untuk berkembang atau dikembangkan, sehingga mungkin saja terjadi seseorang tidak mengetahui dan tidak mengembangkan bakatnya, sehingga tetap merupakan kemampuan yang latent.

Bakat yang mungkin dimiliki seseorang sangat banyak, seperti :

1. Kemampuan verbal reasoning (pemahaman) :

Kemampuan memahami dan menggunakan bahasa baik secara lisan atau tulisan.

2. Kemampuan numerikal (angka) :

Ketepatan dan ketelitian memecahkan masalah aritmatik / konsep dasar berhitung

3. Kemampuan Spatial (ruang bidang) :

Kemampuan merancang suatu benda secara tepat

4. Kemampuan Perceptual :

Kemampuan mengamati dan memahami gambar 2 dimensi 
menjadi bentuk 3 dimensi

5. Kemampuan Reasoning (penalaran) :

Kemampuan memecahkan suatu masalah

6. Kemampuan mekanik :

Kemampuan memahami 2 konsep mekanik dan fisika

7. Kemampuan memori :

Kemampuan mengingat

8. Kemampuan klerikal (administrasi) :

Kemampuan bekerja di bidang administrasi

9. Kreatifitas :

Kemampuan menghasilkan sesuatu yang baru dan menunjuk-kan hal yang tidak biasa / istimewa

10. Kecepatan kerja :

Kemampuan bekerja secara cepat untuk pekerjaan rutin

11. Ketelitian kerja :

Kemampuan bekerja secara teliti

12. Ketahanan kerja :

Kemampuan bekerja secara konsisten

Oleh karena itu harus dilakukan asesmen untuk mengetahui bakat seseorang. Secara spesifik ada 2 tujuan mengapa kita harus mengetahui dan memahami bakat seseorang :

1. Untuk keperluan diagnosis. Dengan mengetahui bakat seseorang, kita bisa mengetahui dan memahami potensi apa yang ada dalam diri seseorang.

2. Untuk keperluan prediksi. Dengan mengetahui bakat seseorang, kita bisa memprediksi apakah seseorang akan bisa sukses atau akan mengalami kegagalan dalam bidang tertentu di masa depan 
Pengukuran bakat-bakat seperti telah dijelaskan di atas akan dibahas di bab IV selanjutnya.

\section{RINGKASAN}

Perilaku manusia selalu dimotivasi oleh potensi yang dimiliki. Selain potensi intelegensi, maka potensi minat dan bakat manusia menjadi potensi yang memotivasi manusia melakukan suatu kegiatan.

Minat adalah suatu proses yang tetap untuk memperhatikan dan menfokuskan diri pada sesuatu yang diminatinya dengan perasaan senang dan rasa puas, sehingga minat dapat menjadi indikator dari kekuatan seseorang di area tertentu dimana ia akan termotivasi untuk mempelajari nya dan menunjukkan kinerja yang tinggi.

Bakat dianggap sebagai salah satu wujud dari kemampuan manusia yang sangat menonjol dibandingkan kemampuankemampuan lainnya.

Bakat seseorang bisa diwujudkan bila kita memberi ruang pada potensi bakat ini untuk berkembang atau dikembangkan. Hal ini menunjukkan bahwa bisa saja seseorang tidak mengetahui kalau dirinya memiliki bakat khusus, sehingga akan tetap menjadi potensi yang tersembunyi (latent) dan tidak ada usaha untuk mengembangkannya.

\section{E. LATIHAN SOAL}

1. Buat kesimpulan pengertian minat dari beberapa pengertian yang ada. 
2. Buat kesimpulan pengertian psikodiagnostik dari beberapa pengertian yang ada.

3. Jelaskan kedudukan minat terhadap bakat yang dimiliki seseorang.

4. Jelaskan sifat bakat

\section{F. REFERENSI}

Anastasi, Anne \& Susana Urbina, 1997. Tes Psikologi. Psychological Testing. Edisi ketujuh.Terjemahan Robertus Hariono S.I. 2007. Penerbit PT. Indeks, Jakarta.

Holland, J. L. (1997). Making vocational choices: A theory of vocational personalities and work environments (3rd ed.). Psychological Assessment Resources

Suryabrata, S (2005). Pembimbing ke Psikodiagnostika 


\section{BAB III TES MINAT}

\section{Kemampuan Akhir Yang Direncanakan :}

Setelah mempelajari bab ini, diharapkan mahasiswa mampu mengidentifikasi masing-masing macam tes minat, yaitu Kuder, RMIB, Holland test (SDS), dII.

\section{A. PENGANTAR}

Tes minat adalah instrumen yang diharapkan bisa mengungkapkan reaksi seseorang menghadapi bermacam-macam situasi, yang secara keseluruhan merupakan cerminan dari minat seseorang, gambaran hal-hal yang disukai oleh seseorang, misal : bagi seorang siswa atau mahasiswa, tes minat akan memberi gambaran bidang pendidikan yang disukai, atau bagi karyawan tes minat ini akan menunjukkan bidang pekerjaan yang disukai.

Minat yang terungkap dari tes seringkali lebih mewakili kondisi minat riil yang dimiliki seseorang dan sifatnya permanen. Hal ini berarti minat yang terungkap dari tes bukan hasil pengaruh dari lingkungan luar, misalkan pengaruh teman atau orangtua. Minat yang terungkap juga bukan minat yang sekedar dipilih seseorang, melainkan memang benar-benar akan memotivasi seseorang untuk mempelajari sesuatu yang disukai.

Berikut akan dijelaskan macam-macam tes minat, antara lain akan dibahas tes minat Kuder, RMIB, Tes Holland

\section{B. MACAM-MACAM TES MINAT 1. Kuder}

\section{a. Pengantar}

Penamaan tes ini diambil dari nama penyusunnya yaitu G. Frederic Kuder. Tes Kuder memfokuskan diri pada pengukuran bidang minat 
yang luas yang mungkin dimiliki seseorang, sehingga hasil tes akan menggambarkan bagaimana minat seseorang pada semua bidang minat yang diungkap tes Kuder, apapun bentuk atau formatnya.

Ada beberapa format tes Kuder, yaitu:

a. Kuder General Interest Survey (KGIS)

KGIS merupakan tes minat yang dikembangkan karena adanya kebutuhan alat tes yang bisa digunakan untuk anak-anak tingkat sekolah menengah pertama atau menengah atas, usia 6-12 tahun dengan bahasa yang bisa dipahami untuk anak usia tersebut. Kuder menyusun tes ini berdasar jawaban yang diberikan subyek coba (yaitu anak-anak) pada 168 kelompok pernyataan macam-macam aktivitas, meliputi minat kejuruan, potensi pekerjaan, atau jurusan pendidikan di perguruan tinggi.

Tujuan dasar penyusunan KGIS oleh Kuder adalah (1) merangsang eksplorasi karir; (2) menyarankan kemungkinan karir yang diminati; atau (3) membuka pilihan minat-minat yang luas, tidak untuk membatasi minat anak-anak.

KGIS memasukkan 10 bidang minat :

(1) Outdoor-minat pada kegiatan yang dilakukan di luar ruangan, misal berurusan dengan tanaman, burung, pengelola ikan, pemasangan saluran telepon, atau petani

(2) Mechanical-minat pada pekerjaan yang ber-hubungan dengan mesin dan peralatan, seperti : tukang kayu, tukang ledeng, atau mekanik.

(3) Computation-minat seseorang pada pekerjaan yang berhubungan dengan angka dan hitungan matematika, seperti : dokter, ahli kimia, ahli diet.

(4) Scientific-minat pada aktivitas yang berkaitan dengan penemuan atau pemahaman tentang alam dan solusi atas suatu masalah, misal

: dokter, ahli kimia, insinyur. 
(5) Persuasive-minat pada kegiatan bertemu dan ber-urusan dengan orang, atau kegiatan yang sifatnya meyakinkan orang lain tentang alasan atau suatu sudut pandang, misal : wirausaha, manajer pribadi, atau pembeli.

(6) Artistic-minat seseorang untuk melakukan peker-jaan yang mengutamakan kreativitas yang meng-gunakan tangan, seperti : seniman, pematung, perancang pakaian.

(7) Literary-minat seseorang pada aktivitas membaca dan menulis, seperti : guru, penyair, editor.

(8) Musical-minat yang berhubungan dengan kegiatan konser, nyanyi, bermain dengan alat musik, mem-baca pengetahuan tentang musik, contohnya : minat menjadi musisi, guru les musik, atau menjadi kritikus musik.

(9) Social Service-minat seseorang pada aktivitas yang sifatnya memberi bantuan pada orang yang membutuhkan

(10) Clerical-minat seseorang pada aktivitas atau pe-kerjaan dengan tugas khusus, seperti : akuntas, pemegang pembukuan, penulis file, $\mathrm{dsb}$.

\section{b. Kuder Occupational Interest Survey (KOIS)}

Tes KOIS merupakan tes minat vocational yang sifatnya self-report. Tes ini seringkali justru dimanfaatkan sebagai instrumen untuk memperoleh data sebelum memberikan bimbingan dan konseling pendidikan kejuruan/vocational. Berbeda dengan KGIS, KOIS ini didesain untuk usia dewasa. Dalam hal jumlah dan bahasa sudah disesuaikan dengan subyek usia dewasa. Tes KOIS terdiri atas 100 item pertanyaan yang menjelaskan beragam aktivitas. c. Kuder Preference Record-Vocational (KPR-V)

Tes Kuder dengan format KPR-V berisi pernyataan-pernyataan yang mewakili 10 bidang pekerjaan, seperti pada KGIS atau KOIS, yaitu : outdoor (pekerjaan lapangan), mekanik, komputasi, science (ilmiah), persuasif, artistik, sastra, musik, pelayanan sosial, clerical 
(sekretaris/kantoran).

Selain 10 bidang pekerjaan itu terdapat subskala, yaitu verifikasi. Subskala ini dimaksudkan untuk mengukur validitas jawaban testee, mengetahui apakah pilihan testee itu jujur dan cermat.

Skor subskala verifikasi akan menentukan apakah pilihan testee akan dilanjutkan diinterpretasi atau tidak. Tujuan penggunaan tes ini di bidang :

(1) pendidikan : bisa digunakan untuk testee yang ingin mengambil studi lanjut.

Pemilihan aktivitas-aktivitas yang disukai saat pengisian tes akan menunjukkan pilihan program studi yang sesuai minatnya, bukan sesuai kemampuannya.

(2) pekerjaan : bisa digunakan untuk membantu perusahaan melakukan seleksi calon karyawan, atau menentukan apakah karyawan yang sudah bekerja telah berada di tipe pekerjaan yang disukai. Untuk mendapat gambaran maksimal, perusahaan tetap harus mempertimbangkan kemampuan karyawan juga, karena seperti diketahui tes minat hanya menggambarkan

b. Bentuk

Secara umum, setiap soal pada tes Kuder terdiri dari 3 pernyataan tentang suatu kegiatan. Testee diminta memilih 2 kegiatan, yaitu kegiatan apa yang paling disukai dan kegiatan apa yang paling tidak disukai. Contoh soal :

$\begin{array}{cc}\text { Kalau } & \text { bepergian } \\ \text { memperhatikan orang-orang } & \\ \text { Kalau } & \text { bepergian } \\ \text { Kemperhatikan pemandangan alam } & \\ \text { Kalau } & \text { bepergian }\end{array}$


memperhatikan hasil-hasil tanaman

Membacakan cerita pada

orang sakit

Mengajar anjing

Membongkar permainan

anak-anak untuk men-getahui bagaimana

dapat membetulkannya

\section{RMIB (Rothwell Miller Interest Blank)}

a. Pengantar

Pada awalnya, di tahun 1947 Rothwell menyusun tes minat. Pada saat itu, tes yang disusun Rothwell memasukkan 9 kategori jenisjenis pekerjaan. Baru di tahun 1958, Kenneth Miller memasukkan 3 kategori jenis pekerjaan baru selain 9 kategori jenis-jenis pekerjaan sebelumnya yang sudah disusun oleh Rothwell, sehingga di tahun 1958 tes RMIB memasukkan 12 kategori jenis pekerjaan. Pengembangan Miller pada tes yang disusun Rothwell menjadikan nama tes ini menjadi Rothwell Miller Interest Blank (RMIB).

Sama seperti tes minat lainnya, tes RMIB diciptakan dengan maksud mengetahui minat yang mungkin dimiliki testee dengan cara mengungkap bagaimana sikap yang ditunjukkan testee pada suatu bentuk pekerjaan, juga bagaimana ide-ide stereotipe yang dimiliki testee tentang pekerjaan yang tersebut.

b. Bentuk 
Tes ini berbentuk blanko/formulir yang berisikan daftar pekerjaan yang disusun dalam 9 kelompok, dengan kode huruf A sampai I, serta dibedakan untuk kelompok pekerjaan pria dan wanitanya.

Masing-masing kelompok pekerjaan tersebut terdiri atas 12 jenis pekerjaan, yang mewakili 9 kategori pekerjaan yang akan diukur dalam tes ini.

Contoh tes RMIB :

\begin{tabular}{|c|c|}
\hline aki-laki & nita \\
\hline etani & Pek erjaan Pertanian \\
\hline nsinyur Sipil & gemudi Kendaraan Militer \\
\hline kuntan & ntan $\quad$ Aku \\
\hline Imuwan & uwan \\
\hline anajer Penjualan & Penj ual hasil-hasil mode \\
\hline eniman & wati Seni \\
\hline artawan & War tawati \\
\hline ianis Konser & Pian is Konser \\
\hline uru Sekolah Dasar & Gur u Sekolah Dasar \\
\hline anajer Bank & Sekr etaris pribadi \\
\hline
\end{tabular}


\begin{tabular}{l|l|ll} 
ukang Kayu & & \multicolumn{2}{|c}{ Per ancang Busana } \\
okter & & ter & Dok \\
\hline
\end{tabular}

Ke 9 kategori pekerjaan yang ada di tes RMIB yaitu :

\section{a. Outdoor}

Pilihan aktivitas yang disukai adalah aktivitas di luar ruangan atau di lapangan terbuka, sehingga pekerjaan yang sesuai adalah pekerjaan yang dilakukan di luar ruangan, tidak berhubungan dengan aktivitas yang dikerjakan di dalam ruang.

Bidang pekerjaan outdoor untuk :

petani, penjaga

aki-laki: hutan, penyelidik, nela-yan, petani tanaman hias, nelayan, supir.

\section{ahli}

. anita : pertamanan, peternak, petani bunga dan tukang kebun, pertanian, guru pendidikan jasmani, pramugari kapal, pembina olahraga.

\section{b. Mechanical}

Pada testee yang suka dengan aktivitas yang mengarah pada bidang mekanik atau teknik, misalnya teknik mesin, teknik sipil, dan sebagainya.

Bidang pekerjaan mechanical untuk :

insinyur sipil, . aki-laki : montir, pembuat jam tangan, tukang las, tukang bubut, tukang listrik, montir, instalator, , pembuat jam tangan 
ahli kacamata, anita: petugas mesin sulam, ahli reparasi permata, ahli reparasi jam

\section{c. Computational}

Bidang minat yang disukai individu yang berkaitan dengan aktivitas berhitung atau bidang yang ada kaitannya dengan angka-angka, misalnya ahli pembukuan keuangan, akuntan, dan sebagainya. Bidang pekerjaan computational untuk :

$$
\text { akuntan, . aki- }
$$

laki auditor, kasir, petugas pajak. pegawai urusan . anita gaji, juru bayar, pegawai pajak, guru IPA. d. Scientific

Bidang minat yang disukai seseorang yang berhubungan dengan bidang scientific.

Minat yang ada kaitannya dengan bidang scientific adalah minat pada pekerjaan yang membutuhkan keaktifan dalam hal analisa dan penyelidikan, eksperimen, kimia dan ilmu pengetahuan pada umumnya, seperti : peneliti, ahli matematika, dan sebagainya. Bidang pekerjaan scientific untuk ilmuwan, ahli aki-laki biologi, ahli astronomi, atau insinyur kimia industri.

ilmuwan, ahli

. anita biologi, ahli pertanian, ahli botani, ahli astronomi, atau asisten laboratorium

\section{e. Personal Contact}

Bidang minat ini merupakan bidang yang disukai seseorang karena berhubungan dengan bidang persuasif. Bidang ini ada pada pekerjaan yang banyak berhubungan dengan kegiatan manusia, dalam bentuk diskusi, membujuk, atau bergaul dengan orang lain, 
misalnya ahli komunikasi, marketing, dan sebagainya. Pada dasarnya minat personal contact mendominasi pekerjaan yang membutuhkan kontak dengan orang lain.

Bidang pekerjaan personal contact untuk :

penyiar radio, aki-laki petugas wawancara, sales asuransi, pedagang keliling

$$
\text { sales }
$$

girl,

anita pegawai rumah mode, penyiar radio, petugas humas

\section{f. Aesthetic}

Bidang minat aesthetic merupakan bidang yang disukai seseorang karena berhubungan dengan bidang seni atau arsitektur.

Pekerjaan ini berhubungan dengan bidang ini bersifat seni dan menciptakan sesuatu, misalnya pelukis, senipatung, arsitek, dan sebagainya.

Bidang pekerjaan aesthetic untuk :

seniman, artis,

aki-laki arsitek, decorator, fotografer dan penata panggung seniwati, guru . anita kesenian, artis, penata panggung

\section{g. Literary}

Bidang minat yang disukai individu yang mengarah pada hal-hal yang berhubungan dengan literatur atau buku-buku, misalnya ahli perpustaan, petugas administrasi, dan sebagainya. Pekerjaan yang berhubungan dengan bidang minat literary biasanya ada kaitannya dengan buku-buku, kegiatan membaca dan mengarang. Bidang pekerjaan literary untuk : 
wartawan,

aki-laki pengarang, penulis skenario, ahli perpustakaan, penulis majalah

wartawan,

anita kritikus buku, penyair, penu-lis sandiwara radio

\section{h. Musical}

Bidang minat musical merupakan bidang yang disukai seseorang karena berhubungan dengan kesenangan melakukan kegiatan di bidang musik, misalnya ahli komposer musik, pemain musik, dan sebagainya.

Minat musical biasanya ada kaitannya dengan kegiatan atau pekerjaan seseorang memainkan alat-alat musik atau untuk mendengarkan orang lain, bernyanyi atau membaca sesuatu yang berhubungan musik.

Bidang pekerjaan musical untuk : pianis

konser, aki-laki komponis, pemain organ, ahli pustaka, dan pramuniaga toko musik pemain organ,

anita guru music, komponis, pianis konser, pramuniaga toko music

\section{i. Social Service}

Bidang minat ini merupakan bidang minat yang disukai seseorang yang mengarah pada aktivitas di bidang pelayanan sosial, misalnya sukarelawan, pekerja sosial, ahli kemasyarakatan, dan sebagainya. Pekerjaan yang didasari minat social service terfokus untuk kesejahteraan masyarakat, yaitu adanya keinginan untuk menolong dan membimbing atau menasehati tentang problem dan kesulitan 
mereka, keinginan untuk mengerti orang lain, dan mempunyai ide yang besar atau kuat dalam hal pemberian pelayanan.

Bidang pekerjaan social service untuk :

$$
\begin{aligned}
& \text { aki-laki psikolog suru pendidikan, } \\
& \text { kepala sekolah, penyebar agama, } \\
& \text { petugas palang merah guru SD, } \\
& \text { anita psikolog pendidikan, petugas } \\
& \text { kesejah-teraan sosial, ahli penyuluh jabatan, } \\
& \text { petugas palang merah j. Clerical }
\end{aligned}
$$

Kategori bakat dan minat yang mengarah pada kemampuan di bidang ketrampilan tangan, misalnya sekretaris, notulen, pembuat kerajinan, dan sebagainya. Minat terhadap tugas-tugas rutin yang menuntut ketepatan dan ketelitian.

Bidang pekerjaan clerical untuk : manajer bank,

- aki-laki petugas arsip, petugas pengiri-man

barang, pegawai kantor, petugas pos, petugas ekspedisi (surat)

\section{sekertaris}

pribadi, juru ketik, penulis steno, pegawai kantor, penyusun arsip

\section{k. Practical}

Kategori bakat dan minat yang mengarah pada kemampuan di bidang praktis, misalnya montir, ahli memperbaiki mesin, dan sebagainya. Minat terhadap pekerjaan-pekerjaan yang praktis, karya pertukangan, dan yang memerlukan keterampilan. Bidang pekerjaan practical untuk : tukang kayu, 
. aki-laki ahli bangunan, ahli mebel, tukang cat, tukan batu, tukang sepatu.

ahli penata . anita rambut, tukang bungkus coklat, tukang binatu, penjahit, petugas mesin sulam, juru masak

\section{Medical}

Kategori bakat dan minat yang mengarah pada kemampuan di bidang medis atau kesehatan, misalnya dokter, perawat, ahli kesehatan dan sebagainya. Minat terhadap pengobatan, mengurangi akibat dari penyakit, penyembuhan, dan di dalam bidang medis, serta terhadap hal-hal biologis pada umumnya.

Bidang pekerjaan medical untuk : dokter, ahli aki-laki bedah, dokter hewan, ahli farmasi, dokter gigi, ahli kacamata, ahli rontgen

dokter, ahli anita bedah, dokter hewan, pelatih rehabilitasi pasien, perawat orangtua

Tes Rothwell Miller dapat diberikan kepada testee secara perorangan maupun klasikal. Testee hanya diminta untuk memberi nomer urut 1-12 di kolom tengah yang kosong, mulai dari pekerjaan mana yang paling disukai untuk dilakukan.

Instruksi biasanya sudah terdapat pada lembar tes sehingga bagi testee yang sudah dewasa dapat diinstruksikan untuk membaca sendiri, kecuali untuk orang dewasa dengan intelegensi rendah (Dullnormal). Testee dengan inteligensi dull-normal perlu diberikan beberapa contoh untuk dapat mengerjakannya dengan tepat, 
dianggap kemampuannya kurang untuk memahami indtruksi tes yang tertulis. Bila perlu saat mereka mengerjakan tester menyempatkan diri untuk memeriksa pekerjaannya. Hal ini dilakukan untuk mengantisipasi jangan sampai testee salah didalam mengartikan instruksi sehingga kemungkinan mereka melakukan kesalahan didalam pengisian jawaban tes.

\section{Self Directed Search (SDS)}

a. Pengantar

Instrumen ini dikembangkan oleh J.L Holland, sebagai instrumen konseling pekerjaan yang bisa dilaksanakan sendiri, diskor sendiri, dan diinterpretasikan sendiri.

Holland membuat konversi bidang minat pada tes Kuder kedalam 6 bidang minat tes Holland yaitu RIASEC. Konversi bidang minat tes Kuder berdasar skala kuder mana yang setara dengan 6 jenis bidang minat tes Holland, yaitu :

(Realistic) Jumlah persentil Outdoor dan

Mechanical dibagi 2

(Investigative) Persentil Scientific

(Artistic)

(Social)

(Enterprising)

(Conventional)
Jumlah persentil Artistic,

Mu-sical, dan Literacy dibagi 3

Mu-sical, dan Literacy dibagi 3

Persentil Social Service

Persentil Persuasive

Jumlah

persentil 


\section{Computatio-nal dan Clerical dibagi 2}

Meskipun SDS dirancang untuk bersifat bisa menemukan skor sendiri, buku panduannya me-rekomendasikan pengawasan tertentu dan pemeriksaan skor. Sebuah studi atas 107 individu yang diseleksi secara acak dari berbagai usia yang mengikuti edisi SDS yang sekarang ada menunjukkan bahwa 7,5\% lebih, telah menarik kode yang memuat atau transposisi yang tidak tepat (Holland, Powell \& Frizche, 1994).

Validitas konkuren dan efisiensi prediktif SDS naik-turun tergantung pada susunan sampel-sampel dalam kaitan dengan usia, jenis kelamin, tingkat pendidikan, dan tipe-tipe distribusi.

b. Asumsi teori

Tes minat ini didasari asumsi Holland :

a. Dalam kebudayaan Amerika, orang-orang dapat dikategorikan sebagai salah satu dari 6 jenis kepribadian yaitu Realistic, Investigative, Artistic, Social, Enterprising dan Convensional. b. Ada 6 jenis model lingkungan kerja yaitu Realistic, Investigative, Artistic, Social, Enterprising dan Convensional. c. Orang mencari lingkungan kerja yang memungkinkan-nya bisa mempraktekkan keterampilan-keterampilan dan kemampuan-kemampuannya, juga bisa mem-praktekkan sikap-sikap dan nilai-nilainya dan me-nerima masalah-masalah dan peranannya yang sesuai.

d. Perilaku seseorang ditentukan atau dipengaruhi oleh interaksi kepribadian dan ciri-ciri lingkungan karirnya.

Asumsi di atas, menurut Holland, berdasar pada 2 hal : 
a. orang dapat digolongkan ke dalam salah satu jenis kepribadian dari 6 jenis.

b. Lingkungan di mana orang-orang itu hidup dapat dikategorikan dalam 6 jenis juga. Lingkungan di sini meliputi budaya, teman

bergaul, orang tua, orang dewasa

Pasangan atau kesesuaian 2 (dua) hal di atas, yaitu jenis kepribadian dan model lingkungan, bisa membantu kita memahami jenis kepribadian dan model lingkungan seseorang. Dengan demikian, perilaku seseorang dapat diketahui melalui interaksi antara pola kepribadian dan lingkungannya.

Pada tes ini, Holland juga merumuskan tipe-tipe (golongan) kepribadian dalam pemilihan pekerjaan berdasarkan atas inventori kepribadian yang disusun atas dasar minat, kemampuan dan kecenderungan dalam menyelesaikan suatu tugas. Tiap-tiap tipe kepribadian individu, memiliki corak yang khas dalam cara penyelesaian sebuah tugas. Corak tersebut juga akan mempengaruhi minat individu dalam menyelesaikan tugas tertentu.

Interaksi tersenut di atas, oleh Holland dikembangkan menjadi instrumen dengan 6 model orientasi sebagai berikut:

1. Tipe Realistik :

Tipe model Realistik memiliki sifat :

a) kurang peka dalam bersosialisasi (berhubungan dengan orang lain)

b) kurang memiliki kecakapan verbal dan hubungan antar pribadi.

c) lebih menyenangi masalah yang konkrit-praktis daripada abstrak-teoritis 


\section{d) mengutamakan kejantanan, kekuatan otot, ketrampilan fisik}

Tipe model ini memiliki kecenderungan untuk memilih lapangan kerja yang berorientasi kepada penerapan:

Pekerjaan yang dipilih yaitu pekerjaan dalam bidang teknik ataupun mesin, seperti : operator mesin/radio, sopir truk, petani, penerbang, pengawas bangunan, ahli listrik, dan pekerjaan lain yang sejenis.

2. Tipe Investigatif

Sifat yang dimiliki individu dengan tipe ini :

a) cenderung berorientasi pada tugas,

b) tidak senang bersosialisasi,

c) berpikir dahulu sebelum bertindak ketika menghadapi masalah,

d) menyenangi tugas yang bersifat abstrak.

Tipe Investigatif ini memiliki kecenderungan untuk memilih pekerjaan yang bersifat akademik, serta memiliki kecenderungan untuk merenungkan daripada mengatasinya dalam memecahkan suatu masalah:

Pekerjaan yang sesuai untuk tipe ini adalah yang bersifat ilmiah, ahli antropologi, astronomi, botani, ahli fisika, ahli biologi, kimia, matematika, pekerjaan penelitian, dan pekerjaan lain yang sejenis.

3. Tipe Artistik

Sifat yang dimiliki individu bertipe ini :

a) sifat yang emosional, impulsif

b) imaginatif,

Tipe model Artistik juga termasuk yang tidak menyenangi hal yang bersifat sosial, sistematis, dan rutin; serta cenderung menghadapi masalah yang terjadi dengan mengekspresikan diri melalui media seni : 
Pekerjaan yang sesuai dengan tipe ini adalah pengarang, pelukis, musisi, penyair, dan seniman, ahli musik, ahli drama, pencipta lagu, dan pekerjaan lain yang sejenis.

4. Tipe Sosial

Sifat yang dimiliki individu dengan tipe ini:

a) memiliki jiwa sosial tinggi,

b) bertanggung jawab,

c) Feminin (kewanitaan),

d) pandai berbicara,

e) memiliki hubungan antar pribadi yang baik

f) bersahabat,

g) persuasif,

h) senang bekerja sama

Seseorang dengan tipe Sosial tidak menyukai kegiatan yang sistematis dan rutin yang melibatkan obyekobyek dan materi, lebih berhubungan dengan perasaan.

Pekerjaan yang sesuai adalah psikolog (klinis), misionari, konselor, pekerja sosial (LSM), guru, pekerja sosial, terapis, dan pekerjaan lain yang sejenis.

\section{Tipe Enterprising}

Tipe model ini dicirikan dengan :

a) Keterampilan verbal yang baik untuk mempersuasi orang lain,

b) fokus terhadap kekuasaan,

c) status,

d) kepemimpinan,

e) bertindak agresif dalam bentuk lisan

Aktivitas yang tidak disukai tipe ini adalah aktivitas yang sistematis, abstrak dan ilmiah, menyukai berbagai macam 
tugas yang menitikberatkan kepada ke-mampuan verbal yang digunakan untuk mengarahkan dan mempengaruhi orang lain. Pekerjaan yang sesuai adalah pemimpin, eksekutif perusahaan, manager, promotor, konsultan, peda-gang, politikus, pimpinan eksekutif perusahaan, perwakilan dagang, dan pekerjaan lain yang sejenis.

6. Tipe Konvensional

Seseorang dengan tipe model ini memiliki ciri-ciri:

a) Memandang diri sebagai pribadi yang teratur, mudah menyesuaikan diri

b) memiliki kemampuan klerikal dan numerikal

c) status dan kekayaan materi merupakan nilai yang dianut

Tipe ini menyenangi kegiatan-kegiatan yang sistematis dan konkrit Pekerjaan yang sesuai adalah ahli statistik, analisis keuangan, ahli perpajakan, penaksir biaya, kasir, pemegang buku, pegawai arsip, pegawai bank, dan pekerjaan lain yang sejenis. c. Bentuk

Ada 3 kelompok soal, yaitu kelompok kegiatan, kelompok kompetensi, dan kelompok pekerjaan, dengan instruksi masingmasing. Masing-masing kelompok terdiri dari kelompok pernyataan $R, I, A, S, E, K$. 
Contoh soal :

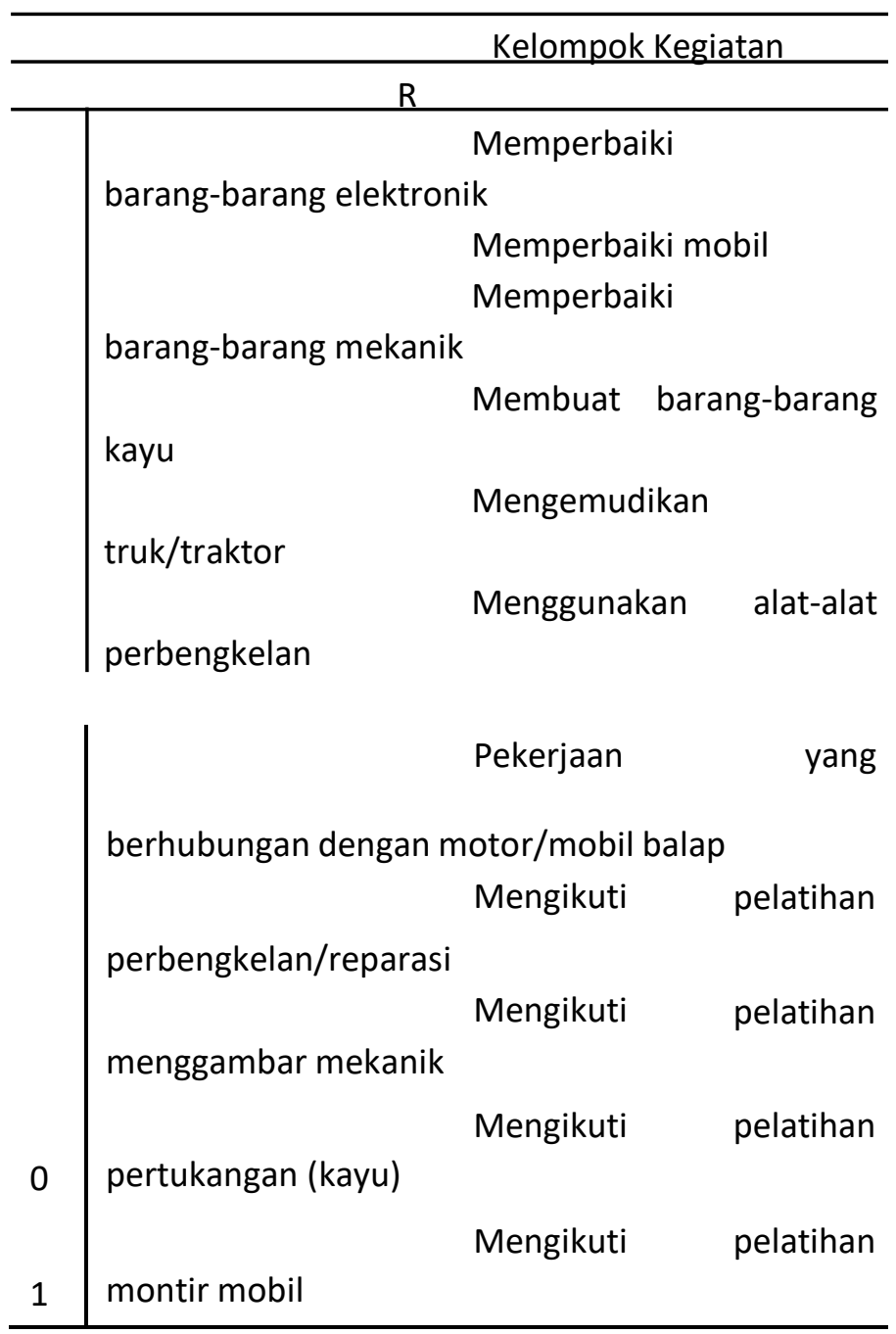




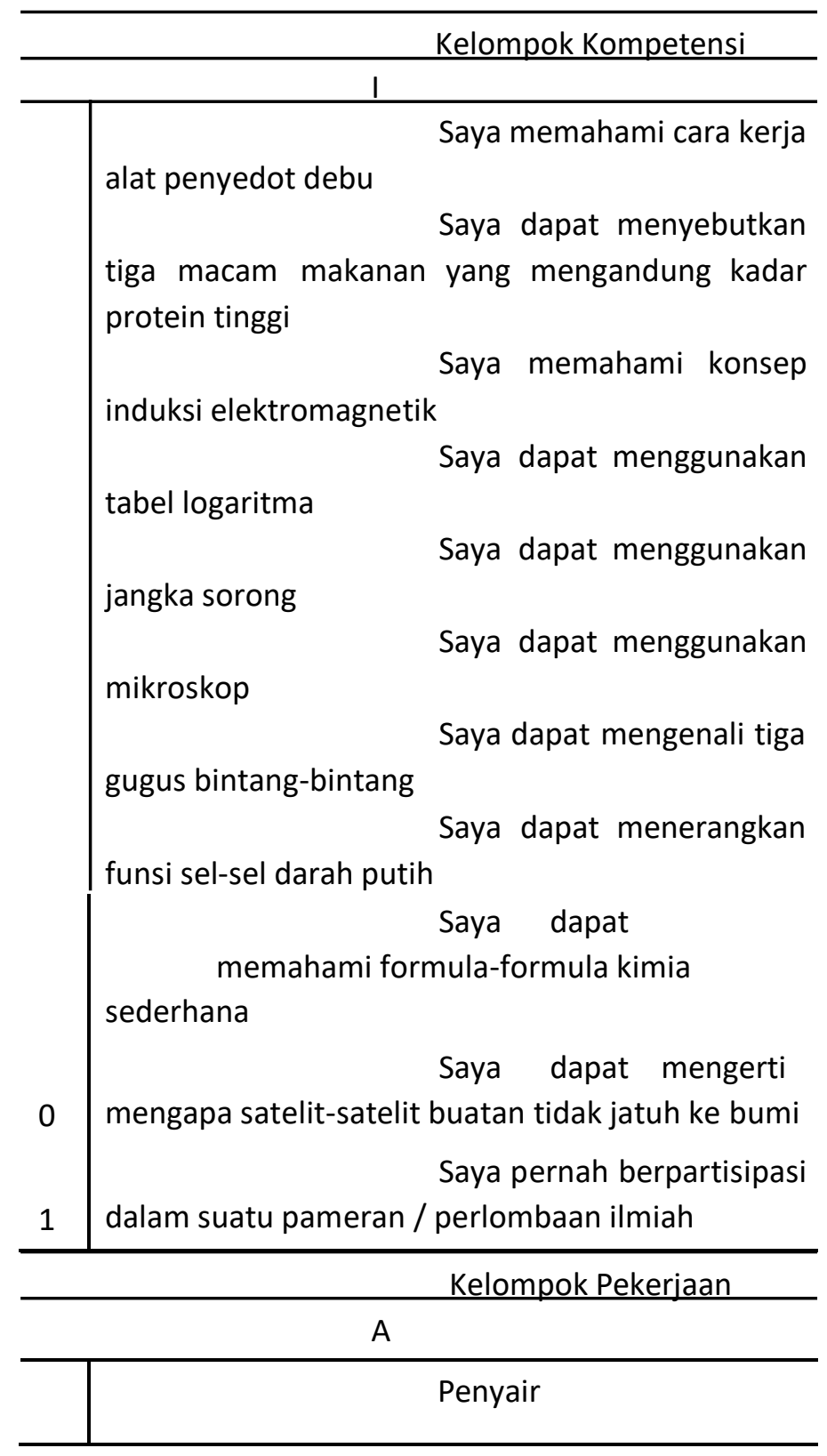




\begin{tabular}{|c|c|}
\hline & Dirijen Orkestra \\
\hline & Musisi \\
\hline & Pengarang \\
\hline & Perancang Iklan \\
\hline & Penulis lepas \\
\hline & Penata musik \\
\hline & Jurnalis \\
\hline & Pelukis \\
\hline 0 & Penyanyi konser \\
\hline 1 & $\begin{array}{l}\text { Komposer } \\
\text { (penggubah lagu) }\end{array}$ \\
\hline 2 & Pematung \\
\hline 3 & Penulis naskah (drama) \\
\hline 4 & Kartunis \\
\hline
\end{tabular}

Testee diminta mengisi lembar Penilaian-Diri yang berisi pernyataan di atas. Karena ini merupakan Self Directed Search, maka setelah mengerjakan tes, testee bisa melakukan skoring sendiri, dan merangkum hasil skoring sehingga akan diperoleh 6 skor rangkuman yang berhubungan dengan tema model Holland (Realistis, 
Investigatif, Artistik, Sosial, Enterprising, dan Konvensional). Kesimpulan hasil tes akan diambil dari 3 skor rangkuman tertinggi, sehingga ditemukan kode berhuruf tiga, misal : A (Artistik) / I (Investigatif) / S (Sosial). Sebuah skor pendamping, Penemuan Pekerjaan, digunakan unutk menemukan pekerjaan diantara 1355 pekerjaan yang kodenya cocok dengan kode rangkuman responden.

\section{Tes-tes Minat Lainnya}

\section{a. SII (Strong Interest Inventory)}

1) Pengantar

Pertama kali diterbitkan pada tahun 1927, dengan nama Strong Vocatinal Interest Blank (SVIB). SIl pertama dirumuskan oleh E.K. Strong.Jr., pada tahun 1919-1920.

SII dewasa ini terdiri dari 317 butir soal yang dikelompokkan dalam delapan bagian. Dalam kelima bagian pertama, responden mencatat preferensinya dengan membuat tanda S, TT, TS, untuk mengindikasikan "Suka", "Tidak Tahu", "Tidak Suka".

Klasifikasi SII atas minat pekerjaan diturunkan dari model teoretis yang dikembangkan oleh Holland $(1966,1985,1992)$ dan didukung oleh riset ekstensif, baik oleh Holland maupun peneliti-peneliti independen lainnya.

General Occupational Themes yang diidentifikasi oleh model Holland ditandai dengan (R) Realistis, (I) Investigatif, (A) Artistik, (S) Sosial, (E) Enterprising, dan (C) Konvensional. Masing-masing tema mencirikan tidak hanya tipe orang, tetapi juga tipe lingkungan kerja yang oleh orang tersebut dirasakan paling menyenangkan.

Menurut Holland, orang-orang tidak digolongkan secara ketat kedalam salah satu dari tipe-tipe utama, melainkan mereka dicirikan 
oleh kadar kemiripan satu tipe dengan tipe lainnya. Dengan demikian, kombinasi tipe semacam ini, yang ditata oleh kadar kemiripan, menyediakan banyak pola atau "kode" untuk mendeskripsikan berbagai perbedaan individu yang luas

2) Bentuk

Butir-butir soal SII terdiri dari lima bagian ini masuk dalam kategori-kategori berikut : pekerjaan, mata pelajaran sekolah, aktivitas (misalnya, membuat pidato, memperbaiki jam atau mencari dana untuk kegiatan amal); aktivitas waktu luang, dan kontak seharihari dengan berbagai jenis orang (misalnya, orang yang amat tua, perwira atau orang yang hidupnya dekat bahaya).

Satu bagian inventori meminta testee untuk memberi tanda pada satu rangkaian pernyataan yang menggambarkan diri sendiri "Ya", "Tidak", atau"?". Dua bagian tambahan meminta testee menyatakan pilihan di antara aktivitas-aktivitas pasangan, misalnya berurusan dengan barang versus berurusan dengan orang, dan di antara semua pasangan yang mungkin dari empat butir soal dari dunia kerja yaitu gagasan, data, barang dan orang.

Disamping hal-hal ini, Form T317 dari SII menghasilkan skor-skor pada empat Skala Gaya Pribadi yang menilai Gaya Pekerjaan,

Lingkungan Belajar, Gaya Kepemim-pinan, dan Pengambilan Resiko/Petualangan.

SII bisa diskor oleh komputer, pada pusat-pusat skoring yang ditunjuk oleh penerbit atau dengan penggunaan perangkat lunak yang tersedia dari penerbit dalam berbagai pilihan. Ada tiga tingkat skor yang berbeda dalam keleluasaannya. Yang paling luas dan paling komprehensif adalah enam skor General Occupational Theme; sub divisi selanjutnya meliputi 25 Basic Interest Scales; dan tingkat yang paling spesifik menyediakan 211 Skala Pekerjaan yang tersedia. 


\section{b. Jackson Vocational Interest Survei (JVIS) \\ a. Pengantar}

JVIS diseleksi untuk mendapat perhatian khusus : pertama, karena JVIS merupakan contoh dari prosedur penyusunan tes canggih, dan kedua, karena dalam berbagai aspek, pendekatannya berlawanan secara tajam dengan diikuti dalam SII. Inventori ini menggunakan area minat yang luas dalam pengembangan butir soal dan sistem penentuan skor. Dalam inventori Strong, sebagian butir soal adalah butir soal Suka, Acuh Tak Acuh, atau Tidak Suka yang ditandai secara terpisah oleh responden.

Selain itu, butir soal Inventori Strong merupakan butir soal bertipe pilihan-terbatas.

Sebagaimana dalam pengembangan Personality Research Form dan Jackson Personality Inventory, langkah pertama dalam pengembangan JVIS adalah merumuskan konstruk-konstruk atau dimensi-dimensi yang harus diukur. Ada 2 (dua) jenis dimensi, yaitu dipilih berdasarkan penelitian yang dipublikasikan tentang psikologi kerja, dan analisis faktor serta klasifikasi rasional atas butir soal minat pekerjaan. Salah satunya dirumuskan yang berkaitan dengan peran kerja (berhubungan dengan pekerjaan atau yang dilakukan seseorang pada pekerjaan) dan dengan gaya kerja (merujuk pada preferensi-preferensi untuk lingkungan kerja atau situasi dimana perilaku tertentu diharapkan).

b. Bentuk

Bentuk final JVIS memuat 34 skala minat dasar, yang mencakup 26 peran kerja dan 8 gaya kerja. Inventori ini dirancang agar dapat diterapkan pada kedua jenis kelamin, meskipun tersedia normanorma persentil terpisah untuk sub-sub kelompok wanita dan pria.

JVIS bisa diberi skor secara manual dengan cepat dan mudah untuk 34 skala. Akan tetapi, pilihan-pilihan penentuan skor berbasis 
komputer yang ada menggunakan norma-norma paling baru dan menyediakan berbagai analisis skor tambahan dalam laporan naratif yang lebih luas yang baru direvisi. Misalnya, laporan-laporan berbasis komputer men-cakup skor-skor yang diturunkan dari analisis faktor atas 34 skala minat dasar. Skor-skor ini yang dibuat menurut model enam tema Holland, mencakup 10 Tema Pekerjaan Umum: Ekspresif, Logis, Bersifat Menyelidik, Praktis, Tegas, Sosial,

Bersifat Membantu, Konvensional, Bersifat Wirausaha, dan Komunikatif.

Sejumlah peninjau mengemukakan bahwa perumusan JVIS mungkin terlalu canggih bagi siswa sekolah menengah (D.T.Brown,1989; J.W.Shepard, 1989).

\section{c. Career Assesment Inventory (CAI) \\ a. Pengantar}

CAI pertama kali dikeluarkan pada tahun 1975, CAI (Johannson,1984) secara dekat mengikuti pola inventori Strong. Berbeda dari kebanyakan inventori minat, CAl dirancang secara khusus untuk para pencari karir yang tidak memerlukan pendidikan universitas selama empat tahun atau pelatihan profesional lebih jauh. CAl berfokus pada pekerjaan yang melibatkan keterampilan, pekerjaan teknis, dan pekerjaan jasa.

Sekarang tersedia dua versi CAI, yaitu The Vocational Version (VV) dan The Enhanced Version (EV). Deskripsi dalam bagian ini adalah VV. Meskipun EV sangat serupa dalam struktur, tetapi instrumen ini sama sekali terpisah (Johannson,1986), yang dapat diterapkan pada banyak dan rentang pekerjaan yang lebih luas, mencakup banyak yang memerlukan pendidikan lewat sekolah menengah.

b. Bentuk 
Tes CAI ini terdiri dari 305 butir soal inventori, yang dikelompokkan dalam tiga kategori isi yaitu : aktivitas, mata pelajaran dan pekerjaan. Masing-masing butir menyediakan lima pilihan respons, dari "sangat suka" sampai "sangat tak suka".

Contoh dari skala-skala pekerjaan yang sekarang tersedia antara lain : montir pesawat, petugas kesehatan gigi, petugas kafetaria, programer komputer, dan perawat terdaftar.

Tes CAl disusun dengan bahasa untuk subyek dengan tingkat membaca kelas 6. CAl juga bisa digunakan pada orang-orang dewasa yang memiliki kemampuan mem-baca yang buruk.

Seperti inventori Strong, CAI menyediakan skor pada tiga tipe skala utama, termasuk 6 skala Tema Umum Holland, 22 skala Bidang Minat Dasar homogen, dan 91 skala pekerjaan.

Indeks administratif dan empat skala non-pekerjaan juga termasuk didalamnya. Semua pengumpulan data dan analisis statistik dijalankan secara terpisah dari inventori ini. Kecuali skala Tema Umum, skala-skala tertentu yang dikembangkan dalam masing-masing kategori ini adalah khusus untuk CAI.

\section{RINGKASAN}

Tes minat adalah instrumen yang mengungkapkan reaksi seseorang terhadap berbagai situasi yang secara keseluruhan mencerminkan minatnya.

Minat yang terungkap dari tes seringkali lebih mewakili kondisi minat seseorang yang sebenarnya dan merupakan minat yang bersifat permanen.

Kuder merupakan tes yang mengungkap minat yang meminta testee melilih kegiatan itu yang paling disukai dan mana yang paling kurang disukai. 
Tes minat Kuder ini dapat digunakan pada tingkat umur yang berbeda, yaitu: (a) Kuder General Interest Survey (KGIS), yang didesain untuk anak-anak usia 6 sampai 12 tahun dengan bahasa yang sederhana; (b) Kuder Occupational Interest Survey (KOIS) yang didesain untuk usia dewasa.

RMIB (Rothwell Miller Interest Blank) adalah tes yang disusun dengan tujuan untuk mengukur minat seseorang berdasarkan sikap seseorang terhadap suatu pekerjaan dan ide-ide stereotipe terhadap pekerjaan yang bersangkutan.

Self Directed Search (SDS) adalah instrumen minat yang dikembangkan oleh J.L Holland, sebagai instrumen konseling pekerjaan yang bisa dilaksanakan sendiri, diskor sendiri, dan diinterpretasikan sendiri, yang berhubungan dengan tema model Holland (Realistis, Investigatif, Artistik, Sosial, Enterprising, dan Konvensional).

Selain ketiga tes minat di atas, ada tes minat Lain, yaitu (1) SII (Strong Interest Inventory); (2) JVIS (Jackson Vocational Interest Survei); dan (3) CAI (Career Assesment Inventory)

SII (Strong Interest Inventory). Klasifikasinya atas minat pekerjaan diturunkan dari model teoretis yang dikembangkan oleh Holland (pada General Occupational Themes), dan didukung oleh riset ekstensif, baik oleh Holland maupun peneliti-peneliti independen lainnya.

JVIS (Jackson Vocational Interest Survei). JVIS memiliki prosedur penyusunan tes canggih dan pendekatannya berlawanan secara tajam dengan diikuti dalam SII. Inventori ini menggunakan area minat yang luas dengan 2 dimensi yaitu peran kerja (berhubungan dengan pekerjaan atau yang dilakukan seseorang pada pekerjaan) dan dengan gaya kerja (merujuk pada preferensi-preferensi untuk lingkungan kerja atau situasi dimana perilaku tertentu diharapkan). 
CAI (Career Assesment Inventory). CAl mengikuti pola inventori Strong. Akan tetapi CAl dirancang secara khusus untuk para pencari karir yang tidak memerlukan pendidikan universitas selama empat tahun atau pelatihan profesional lebih jauh.

\section{LATIHAN SOAL}

1. Jelaskan apakah tes minat efektif mengukur minat?

2. Sebutkan perbedaan dari masing masing tes minat!

3. Dari 3 tes minat pertama (Kuder, RMIB, SDS), mana yang penggunaanya paling praktis, jelaskan!

\section{E. TUGAS}

Buat kelompok yang terdiri dari 3-4 orang. Tugasnya adalah (a) mempelajari salah satu tes minat, (2) menjelaskan salah satu tes minat yang dipelajari, (3) mempraktekkan administrasi tes minat tersebut.

\section{F. REFERENSI}

Alsa, A, dkk. (2004). Informasi Tes. LPKM Fakultas Psikologi Universitas Gadjah Mada.Divisi Ritel.Jogjakarta Anastasi, Anne \& Susana Urbina, (1997). Tes Psikologi. Psychological Testing. Edisi ketujuh. Terjemahan Robertus Hariono S.I. 2007. Penerbit PT. Indeks, Jakarta.

HIMPSI (2000). Materi Penyegaran Psikodiagnostik.

Holland, J. L. (1997). Making vocational choices: A theory of vocational personalities and work environments (3rd ed.). Psychological Assessment Resources. 
Marnat, G.G. (2009). Handbook of Psychological Assessment. Fifth Edition. Alih bahasa : Drs. Helly P.P, MA. \& Dra. Sri Mulyantini S., 2010. Cetakan I. Pustaka Pelajar, Yogyakarta.

Rothwell \& Miller, K. (....). Petunjuk Penggunan Tes: Inventarisasi Minat The Rothwell-Miller Interest Blank (Manual Test RMIB). Diedit dan disusun kembali : Staf LPSP3 Fakultas Psikologi UI. Penerbit LPSP3 Fakultas Psikologi Universitas Indonesia. 


\section{BAB IV}

TES

BAKAT

Kemampuan Akhir Yang Direncanakan :

1. Mahasiswa mampu mengidentifikasi masing-masing macam tes bakat kelompok, yaitu : DAT, GATB, FACT.

2. Mahasiswa mampu mengidentifikasi masing-masing macam tes bakat tunggal, yaitu : kraepelin, dll.

\section{A. PENGANTAR}

Tes Bakat dan Minat mulai berkembang setelah muncul ketertarikan untuk mengetahui Bakat Khusus, yaitu tes yang dimaksudkan untuk mengetahui kecenderungan kemampuan khusus pada bidang-bidang tertentu. Tes Bakat adalah tes yang dirancang untuk mengukur kecenderungan kemampuan potensial yang dimiliki seseorang dalam satu jenis aktivitas khusus.

Mulai muncul usaha penyusunan tes-tes secara terpisah untuk mengukur potensi bakat. Ada beberapa macam Tes Bakat, baik yang multiple maupun yang tunggal. Selanjutnya, akan dibahas beberapa tes bakat, dan pembahasannya hanya berkisar pada potensi apa yang digali oleh masing-masing tes bakat. Beberapa jenis tes akan disertai contoh soalnya, terutama tes yang nanti akan dibahas lebih detil, yang bisa dicoba dipraktekkan. 


\section{B. MACAM-MACAM TES BAKAT}

Secara umum, tes bakat terdiri dari : Multiple Aptitude Batteries, dan Special Aptitude Test.

\section{Multiple Aptitude Batteries (Tes bakat Multiple)}

Tes bakat multiple, atau Multiple Aptitude Batteries, adalah tes yang terdiri dari sejumlah tes dan digunakan untuk menganalisis profil individu (Anastasi, 1997). Tes yang dirancang bisa digunakan untuk mengukur kemampuan Siswa Sekolah Menengah Atas untuk belajar atau berhasil di bidang-bidang tertentu.

\section{a. DAT (Differential Aptitude Tests)}

Penyusunnya : George K. Bennet, Harold G. Seashore, \& Alexander G. Wesman pada tahun 1947.

DAT disusun berdasar konsep yang menyatakan bahwa kemampuan mental tidak hanya terdiri dari satu faktor saja melainkan banyak faktor sehingga dibutuhkan suatu tes yang dapat mengukur bermacam-macam faktor dengan beberapa skor sesuai dengan kemampuan yang diukur.

Alasan menggunakan DAT :

1. Membantu siswa memiliki pilihan pendidikan dan karir

berdasarkan kelebihan dan kelemahan potensinya

2. Membantu siswa memahami kelebihan dan kelema-hannya pada

bidang-bidang tertentu dengan lebih baik

3. Memperluas cakrawala atau wawasan siswa dengan menyarankan opsikarier baru dan yang diperluas yang konsisten dengan kemampuan yang teruji

4. Meningkatkan aspirasi pekerjaan atau mengubah arahnya 


\section{Memotivasi siswa yang kurang berprestasi dengan}

mengidentifikasi kekuatan yang tidak diakui atau diremehkan

6. Melengkapi data pencapaian yang sudah ada untuk memfasilitasi masuk ke kursus pendidikan atau magang

7. Untuk pengalaman, beberapa kursus / karier memiliki tes jenis yang serupa

DAT terdiri dari :

\section{Verbal Reasoning}

\section{a. Pengantar}

Tes ini Mengukur : kemampuan berpikir abstrak, generalisasi, konstruktif dengan memahami konsep verbal. Tes ini penting diberikan kalau kita berhadapan dengan pekerjaan yang membutuhkan mengkomunikasikan ide atau me-mahami materi tertulis.

Dengan demikian, pemberian tes ini diharapkan bisa memperkirakan apakah seseorang akan berhasil bila masuk di bidang yang harus kuat dalam hal mengkomunikasikan ide atau memahami materi tertulis, misal : bidang hukum, jurnalistik, pekerja sosial, seni, media, public relation, periklanan, dsb.

b. Bentuk

Perbendaharaan kata dalam bentuk analogi sederhana yang didasarkan pada asosiasi.

\section{Contoh soal :}

... adalah untuk malam seperti sarapan adalah untuk ...
A. supper..... pojok
B. lembut... .. breakfast
C. pintu..... sudut
D. aliran.... .. nikmati
E. supper..... breakfast 


\section{Tes Berhitung (numerical ability)}

\section{a. Pengantar}

Disebut juga dengan Arithmatic Computation. Tes ini mengukur :

1. kemampuan berpikir dengan angka

2. penguasaan hubungan numerik

3. memecahkan masalah yang berhubungan dengan konsep

numerik, misal : penjumlahan sederhana

Tes ini dibuat untuk:

a. Pelajaran : matematika, fisika, kimia, teknik, ekonomi, akuntansi, atau sejenisnya.

b. Pekerjaan : asisten laboratorium, keuangan, akuntansi, perbankan, arsitektur, mesin, dan sejenisnya. b. Bentuk Pengerjaan hitungan sesuai permintaan soal.

Contoh soal :

Penambahan
30
A. 8
20
B. 15
C. 10
D. 25
E. tak ada satupun yang benar

3. Tes Penalaran (abstract reasoning)

\section{a. Pengantar}

Tes ini mengukur :

Kemampuan penalaran yang bersifat non verbal, yaitu pengukuran kemampuan memahami adanya hubungan yang logis pada konsep abstrak. Apakah seseorang memiliki kemampuan yang baik dalam hal penalaran pada gambar atau desain geometris Tes ini dibuat untuk: 
Pelajaran atau pekerjaan yang memerlukan

kemampuan mempersepsi hubungan antar benda, seperti :

(1) Pelajaran : fisika, kimia, biologi, sejarah, musik, seni, atau sejenisnya

(2) Pekerjaan : ahli mesin, dokter, guru, programer komputer,

mekanik, dan sejenisnya

b. Bentuk

Masing-masing soal tes ini berbentuk 4 rangkaian gambar atau desain geometris yang memiliki urutan, dan testee harus menentukan bagaimana bentuk gambar atau desain urutan gambar selanjutnya, yaitu gambar ke lima Contoh soal : soal

Jawaban
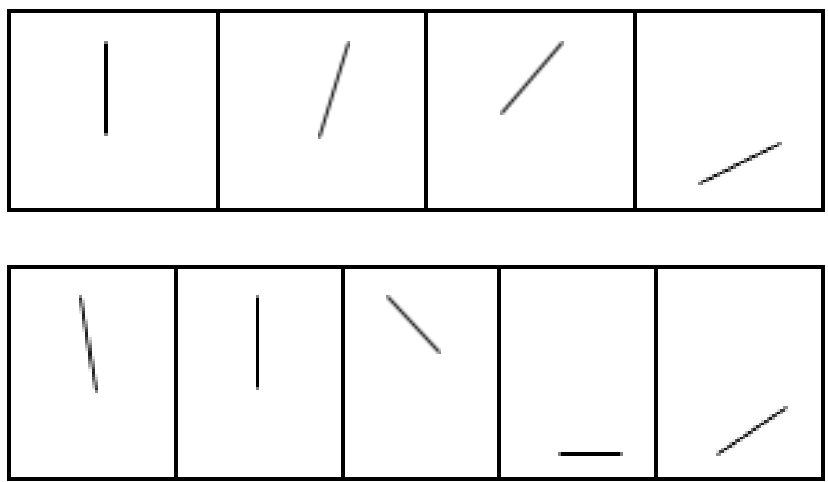

4. Tes Pola (Space Relation)

\section{a. Pengantar}

Tes ini mengukur :

Kemampuan mengenal obyek kongkrit melalui proses penglihatan secara 3 (tiga) dimensi dari pola 2 dimensi, karena kemampuan ini membutuhkan kemampuan memanipulasi pola atau bentuk secara menta, apakah seseorang memiliki kreasi untuk menstruktur suatu barang atau bentuk tertentu dengan perencanaan yang baik Tes ini dibuat untuk : 
Prediksi pekerjaan : bidang teknik, arsitektur, seni, desain busana, fotografi, geometri bidang b. Bentuk

Soal berupa gambar pola 2 dimensi yang harus dibentuk (dikonstruksikan) menjadi pola 3 dimensi.

Contoh soal :

Testee diminta membentuk pola soal di sebelah kiri menjadi suatu bangun benda $(A, B, C, D, E)$ di sebelah kanan

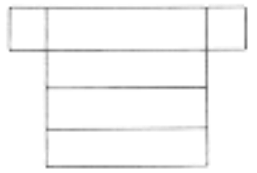

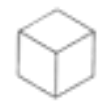

A.

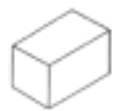

s

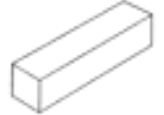

c

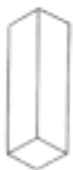

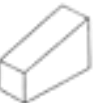

E

5. Tes Pengertian Mekanik (Mechanical Reasoning)

\section{a. Pengantar}

Tes Pengertian Mekanik mengukur :

Daya penalaran di bidang kerja mekanik dan prinsip fisika Tes ini dibuat untuk :

Mengetahui kemampuan khusus dalam bidang mekanik, memahami prinsip dasar mekanik dari mesin

Bidang pekerjaan : tukang kayu, ahli mesin, pemeliharaan mesin, perakit (asembling), elektronik, dan sejenisnya

b. Bentuk

Soal berupa gambar disertai pertanyaan yang ada hubungannya dengan gambar Contoh soal :

mana

berputar

arah A, atau

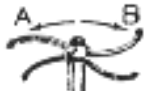

jawabannya $\mathrm{C}$.
Testeedimintauntuk menen-tukan kearah

kincirpada soal akan seandainyaair dialirkan. Ke $B$, ataukalau sembarang 
6. Tes Cepat dan Teliti (Perceptual Speed and Accuracy)

a. Pengantar Tes

ini mengukur :

a. Kemampuan seseorang untuk membandingkan dan menandai daftar yang tertuli secara cepat dan tepat.

b. Respon subyek terhadap tugas-tugas atau peker-jaan yang menyangkut kecepatan persepsi pada stimulus yang bersifat sederhana

c. Kecepatan respon terhadap kombinasi huruf dan angka

d. Ingatan yang sifatnya tidak lama

Tes ini penting diberikan untuk : pekerjaan ilmiah atau pekerjaan yang sifatnya teknis yang membutuhkan "presisi", selain meramal produktivitas mengerjakan pekerjaan rutin yang melibatkan masalah persepsi, sehingga seorang pekerja mampu membandingkan dan memberi tanda-tanda pada daftar tulisan secara cepat dan tepat.

Pekerjaan clerical, seperti : filling (pengisian file), coding (pemberian kode), stock room work (pekerjaan ruang persediaan)

b. Bentuk

Setiap soal terdiri dari pasangan huruf-huruf atau angka-huruf, dan salah satu pasangan tersebut diberi garis bawah. Lembar jawaban terdiri dari pasangan huruf-huruf atau angka-huruf yang salah satu pasangan sama dengan pasangan di soal.

Tugas testee memberi garis bawah pasangan tersebut di lembar jawaban seperti pasangan bergaris bawah di soal.

Contoh soal : soal jawaban :
1. $A B A C A D$ Ae $A F$
1. $A b C d A B C F a E$
2. $A a$ aB Ba $\underline{B A} B b$
2. $B A B b$ bA ba $A a$
3. $A 77 A B 77 B$ 3. a7 b7 AB 7a B7 
7\&8. Language Usage : I. Spelling ; II. Sentences

a. Pengantar

Tes ini terdiri dari 2 tes :

\section{Spelling}

Mengetahui perbendaharaan kata yang sering digunakan dalam kehidupan sehari-hari

\section{Sentences}

Mengukur kemampuan membedakan tata bahasa yang baik dengan yang jelek, memahami pemberian tanda baca yang tepat dan penggunaan kata yang tepat dalam bahasa inggris

Tes ini dibuat untuk : bidang jurnalistik (menulis), mengajar, korespodensi bisnis. b. Bentuk

1. Tes spelling, contoh soal :

Kata mana yang tidak dieja dengan benar
A. cycle
B. gurl
C. arrowD. wrote

2. Tes sentences, contoh soal :

A. Ali \& Ibnu / akan memotong / halaman berumput/ akhir minggu ini

B. Ali \& Ibnu / akhir minggu ini / akan memotong / halaman berumput /

C. Akhir minggu ini /Ali \& Ibnu / akan memotong / halaman berumput

D. Akan memotong / halaman berumput / akhir minggu ini / Ali \& IbnuJawaban :
A
B
C
D
E. betul semua

\section{b. GATB (General Aptitude Tests Battery)}

Diciptakan oleh Charles E. Odell dari The United State Employment Services (USES ), tahun 1947. GATB adalah suatu alat tes yang berhubungan dengan jabatan yang berorientasi pada beberapa tes bakat baterai. 
GATB terdiri dari :

12 sub tes yang bisa digunakan untuk mengukur 9 kemampuan dasar atau bakat.

\section{General Learning Ability}

Kemampuan belajar secara umum, meliputi :

a. kemampuan untuk menangkap dan mengerti prinsip-prinsip

b. kemampuan untuk penalaran dan membuat keputusanSubtes-nya

a. Vocabulary (perbendaharaan kata)

b. Arithmetic Reasoning (penalaran aritmatik),

c. Three Dimentional Space (ruang bidang)

\section{Verbal Aptitude}

Kemampuan untuk mengerti arti dari beberapa

kata dan mempergunakannya dengan efektif, meliputi :

a. kemampuan untuk mengerti bahasa secara komprehensif

b. mengerti hubungan antar kata

c. mengerti arti keseluruhan kalimat dan paragrafSubtes-nya :

1. Vocabulary (perbendaharaan kata)

\section{Numerical Aptitude}

Kemampuan untuk melakukan operasi-operasi angka-angka secara cepat dan tepat, meliputi :

a. komputasi maupun penalaran aritmatik Subtesnya :

\section{Computation}

2. Arithmatic Reasoning

4. Spacial/Three Dimentional Space (Tes Ruang Bidang)

Kemampuan untuk berpikir secara visual pada bentuk-bentuk geometris dan kemampuan untuk menangkap obyek tiga dimensi. 
Subtes-nya :

1. Three Dimentional Space (ruang bidang)

5. Form Perception (Tes Mempersamakan Perkakas)

Kemampuan untuk melihat bagian-bagian dari suatu benda, gambar dan grafik secara cepat dan akurat, meliputi :

a. kemampuan untuk membuat perbandingan dan pembedaan secara visual

b. melihat perbedaan yang nyata pada bentuk atau bayangan (shading) dari suatu figur dan panjang lebar suatu garis Subtes-nya

1. Tool Matching

2. Form Matching

\section{Clerical Perception}

Kemampuan untuk mengungkap obyek-obyek klerikal (angka dan huruf), meliputi :

a. kemampuan persepsi terhadap komputasi secara sepintas

b. mirip dengan Form Perception tetapi memerlukan penggabungan nama-nama dari pada gambar-gambar atau bentuk-bentuk Subtes-nya :

\section{Name Comparison}

\section{Motor Coordination}

Tes ini disebut juga tes mengikuti jejak atau memberi kode.

Tes ini mengukur :

Kemampuan untuk mengkoordinasikan gerakan-gerakan organ mata, tangan, atau jari-jari tangan dengan terampil dan teliti dalam gerakan yang tepat dan cepat Subtes-nya :

1. Mark Making 


\section{Finger Dexterity (Tes Kecepatan Jemari)}

Tes ini mengukur :

Kemampuan gerakan jari-jemari, meliputi :

a. memanipulasi obyek-obyek kecil dengan jari jemari secara cepat dan teliti

Subtes-nya :

\section{Assemble (merakit) \\ 2. Disassemble (membongkar)}

9. Manual Dexterity Tes

ini mengukur :

Kemampuan untuk menggerakkan tangan dengan mudah dan terampil, meliputi : kemampuan seseorang bekerja dengan tangan (menempatkan dan memindahkan sesuatu) Subtes-nya :

1. Place test

2. Turn test

Dari 9 tes, ada 12 macam sub tesnya adalah :

1. Tes perbandingan nama (name comparison)

2. Tes komputasi (perhitungan)

3. Tes tiga dimensi (three dimentional space)

a. Pengantar

Tes ini disusun untuk membantu kita mengetahui kemampuan berpikir yang dimiliki seseorang, terutama kemampuan berpikir secara visual dari bentuk geometri, Bagaimana seseorang me-mahami gambar 2 dimensi dipikirkan secara visual menjadi gambar 3 dimensi. b. Bentuk contoh soal : 


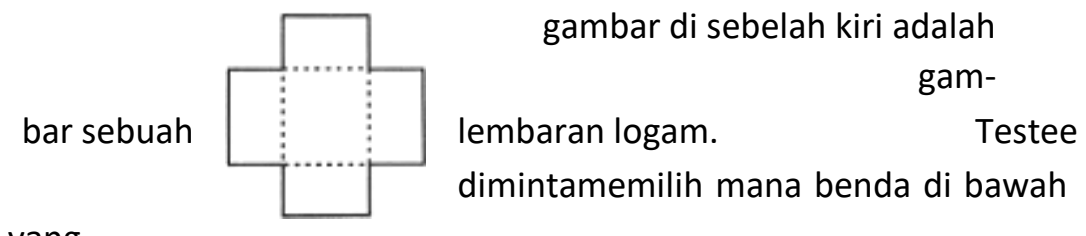

yang

memilikibentuk yang tepat seperti gambar soal jawaban :

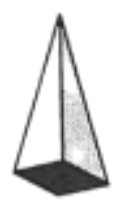

A

B

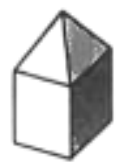

C
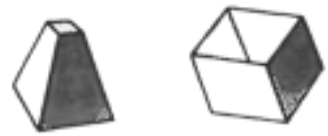

D

Tes ini dianggap mampumengungkap inteligensi bila diukur bersama dengan 2 sub tes lain dari kelompok tes GATB, yaitu :

1. Tes Perbendaharaan kata (Vocabulary)

2. Tes Berhitung (Arithmatic Reasoning)

4. Tes perbendaharaan kata (vocabulary)

5. Tes memasangkan alat (tool matching)

Tes ini disusun khusus untuk mengetahui apakah seseorang memiliki kemampuan atau kecermatan dalam pengamatan, khususnya pada alat-alat khusus. Tes ini membantu mengetahui bakat siswa untuk mengikuti pendidikan kejuruan.

6. Tes berhitung (Arithmatic Reasoning)

7. Tes memasangkan bentuk (form matching)

8. Tes membuat tanda (mark making)

9. Tes meletakkan (place test) 
10. Tes membalik (turn test)

11. Tes merakit (assemble) Finger-dexterity

12. Tes mengurai (disassemble)

\section{c. FACT (Flanagan Aptitude Classification Tests)}

Diciptakan oleh John. C. Flanagan (USA). FACT Terdiri dari :

1. Tes Inspection

a. Pengantar

Tes ini digunakan untuk menguji ketajaman persepsi visual secara detail (sehingga tesnya dapat disebut tes persepsi detail). Kemampuan ini dibutuhkan dalam memeriksa hasil-hasil pabrik yang hampir selesai atau sudah selesai.

b. Bentuk

Tes ini mengukur kemampuan untuk menemukan kekurangan atau ketidaksempurnaan dalam serangkaian artikel dengan cepat dan akurat. Oleh karena itu tes ini dirancang dalam bentuk gambar, obyek, atau rangkaian artikel yang memiliki kekurangan

2. Coding (Tes Kode dan Ingatan)

\section{a. Pengantar}

Tes ini digunakan untuk mengukur kode (ke-cepatan dan ketelitian testee dalam memberi kode atau sandi khusus perkantoran (artificial office information), dan ingatan (mengingat sandi/kode atau menghafal bahan-bahan cetakan).

b. Bentuk

Soal untuk sub tes coding terbagi menjadi 2, yaitu soal sandi/kode dan soal ingatan.

\section{Memory}




\section{a. Pengantar}

Mengukur kemampuan mengingat dan menyebutkan kembali kode-kode yang telah dipelajari dalam tes pengkodean

\section{Precision}

\section{a. Pengantar}

Tes ini ingin mengukur kecepatan dan keakuratan dalam gerakangerakan jari secara melingkar dengan satu tangan dan dengan dua tangan. Biasanya kemampuan ini dibutuhkan untuk pekerjaan yang membutuhkan kecepatan bekerja pada obyek-obyek kecil.

\section{Assembly (Merakit Obyek)}

\section{a. Pengantar}

Tes ini disusun untuk mengetahui kemampuan visual testee didalam mengenal, mengetahui, dan membayangkan bentuk suatu obyek yang disusun dari bagian-bagian yang terpisah-pisah, tanpa model yang sesungguhnya dan berupa tes bidang 3 dimensi.

b. Bentuk

Tes ini terdiri dari 2 bagian yang masing-masing bagian terdapat soal dalam bentuk beberapa bagian yang harus dirakit, dan testee diminta membayangkan akan membentuk obyek rakitan tertentu dengan dibatasi waktu pengerjaannya. Contoh soal :

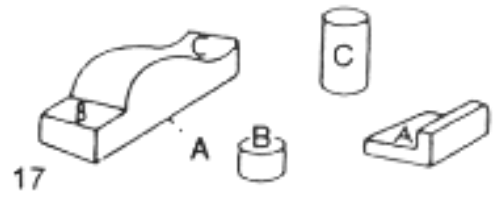

Testee diminta merakit gambar soal menjadi bentuk rakitan yang sesuai dengan soal : 


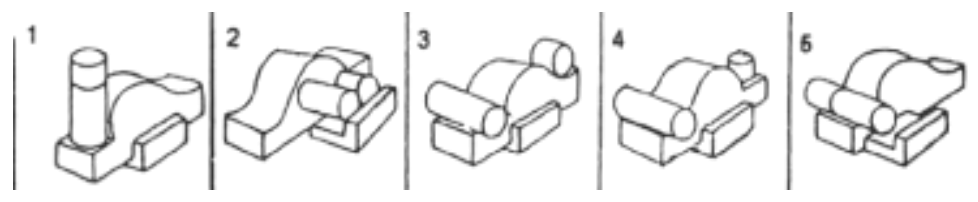

6. Scales (Tes Skala dan Grafik)

a. Pengantar

Dengan melihat nama tes maka tes ini memang dimaksudkan untuk mengetahui kemampuan testee membaca skala, grafik, atau peta dengan cepat dan tepat.

Menurut Flanagan, tes ini dibutuhkan untuk melihat kemampuan Critical Fact Element, yang harus ada pada : bilogical scientist, chemist, draftman, engineer, nurse, physician, pilot airplane.

b. Bentuk

Soal tes ini berupa bentuk-bentuk yang biasa terdapat pada bidang yang berhubungan dengan mesin atau bidang teknik lain pada umumnya.

\section{Coordination}

a. Pengantar

Mengukur kemampuan untuk mengkoordinasikan gerakan lengan dan tangan (hand and arm coordination)

8. Judgment and Comprehension (Tes Pemahaman)

a. Pengantar

Tes ini bisa digunakan kalau kita ingin mengetahui kemampuan testee membaca dan memahami suatu situasi praktis, khususnya 
melihat alasan logis tentang situasi yang ada dan kemampuan mengambil keputusan berdasar makna yang ditangkap testee pada suatu situasi praktis.

\section{b. Bentuk}

Tes ini ini terdiri dari beberapa cerita atau situasi, dan di setiap akhir cerita diberi beberapa pertanyaan sesuai dengan cerita atau situasi yang digambarkan sebelumnya.

Contoh soal :

Mardi telah dinyatakan diterima sebagai pegawai penjaga ketel uap. Dia tahu secara umum bahwa air dipanaskan dalam ketel untuk membuat uap, dan uap ini digunakan untuk menggerakkan mesinmesin dalam pabrik, termasuk mesin pembangkit tenaga listrik. Akan tetapi bagian-bagian kecil dalam tugasnya baru akan diterangkan kemudian. Pemimpinnya menunjukkan kepadanya klep bahaya dan menerangkannya bahwa pada tekanan 12 atmosfir klep bahaya itu akan terbuka dengan sendirinya.

Dia menunjukkan pula kepadanya klep lain yang mengawasi banyaknya air yang mengalir ke dalam ketel, dan menerangkan bahwa tinggi permukaan air dalam tabung pengawas air sedikitnya harus berisi setengah, untuk menjaga agar ketel tidak terlanjur menjadi kering. Dia memperhatikan juga bagaimana mengawasi besarnya tekanan uap yang sedang dibuat.

Pertanyaannya antara lain :

Membuka klep untuk memungkinkan lebih banyak air mengalir ke dalam ketel akan mengakibatkan :
a. naiknya tekanan uap mendekati 25 atmosfir
b. turunnya permukaan air dalam tabung penga-was air
c. berkurangnya tekanan uap
d. terbukanya klep bahaya 


\section{Arithmatic}

\section{a. Pengantar}

Dari namanya maka tes ini dimaksudkan untuk mengukur kemampuan berhitung dalam bentuk 4 penjumlahan, pengurangan, pengalian, dan pembagian.

\section{Patterns (Tes Mengutip)}

\section{a. Pengantar}

Tes ini disusun untuk mengungkap kemampuan testee didalam mereproduksi outline pola-pola sederhana secara akurat. Kalau dilihat, tes ini bisa digunakan untuk milhat apakah seseorang memiliki kemampuan di bidang merancang desain, mem-baca blueprint dan diagram teknis, atau sketsa-sketsa, yang biasa dihadapi arsitek, periklanan, perancang mode, dan sebagainya. b. Bentuk Tes ini terdiri dari 2 bagian : bagian pertama berisi 18 pola, dan bagian II berisi 12 pola. Pola soal memiliki taraf kesulitan yang makin meningkat, dengan waktu pengerjaan yang dibatasi.

\section{Components (Tes Komponen)}

\section{a. Pengantar}

Tes ini digunakan untuk mengetahui kemampuan testee didalam mengidentifikasi komponen-komponen yang dianggap penting.

b. Bentuk

Contoh soal :

Ada 5 gambar sederhana di bawah :

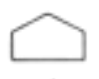

A

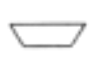

B
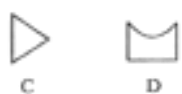

D

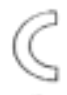

E

Testee diminta untuk menentukan mana dari kelompok gambar di atas yang menjadi bagian dari gambar soal di bawah : 
a.

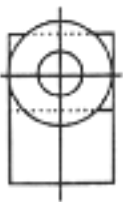

A B C D E

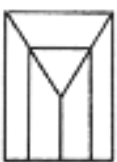

A B C D E

b.

\section{Tables (Tes Tabel)}

\section{a. Pengantar}

Seperti namanya, tes ini memang untuk membaca tabel, terutama tabel yang isinya 2 macam. b. Bentuk

Tes ini berbentuk lembaran, ada 2 lembar di 4 halaman. Halaman 1 dan 3 isinya petunjuk pengerjaan soal disertai contoh. Halaman 2 dan 4 berisi soal yaitu dalam bentuk soal tabel. Tabel pertama terdiri dari angka; dan tabel kedua berisi kata dan huruf alphabet.

Contoh soal :

Tabel di bawah menunjukkan nama-nama pabrik yang memproduksi macam-macam tipe "bagian mesin"

\begin{tabular}{|l|l|l|l|l|}
\hline $\begin{array}{l}\text { agian } \\
\text { mesin }\end{array}$ & ipe A & ipe B & ipe C & ipe D \\
\hline s & OBA & AYA & BC & ARNA \\
\hline ait & AMA & ARNA & AYA & BC \\
\hline opling & ARNA & BC & AYA & OBA \\
\hline
\end{tabular}

Soal :

Testee diminta memberi silang pada pabrik yang memproduksi bagain mesin seperti pada soal : 


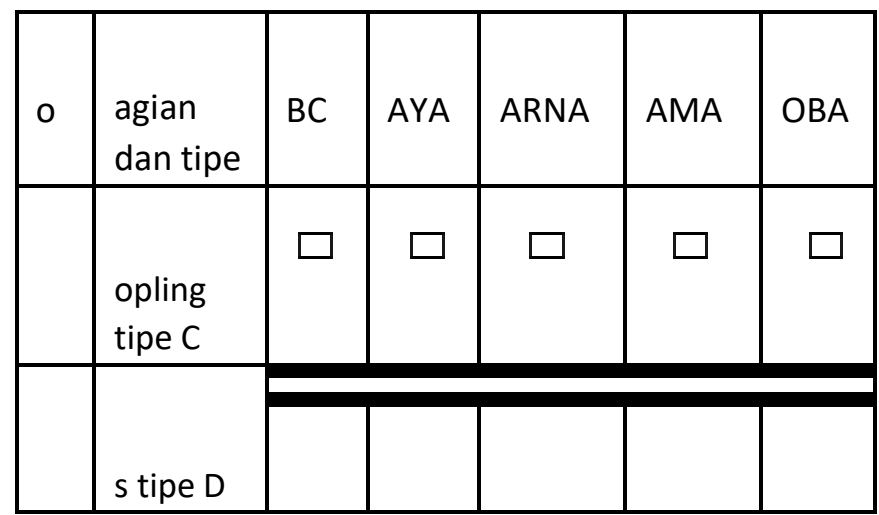

\section{Mechanics}

\section{a. Pengantar}

Tes ini bisa dimafaatkan bika kita ingin mengukur kemampuan pemahaman prinsip-prinsip mekanika dan kemampuan menganalisis gerakan-gerakan mekanika.

b. Bentuk : Contoh soal ....

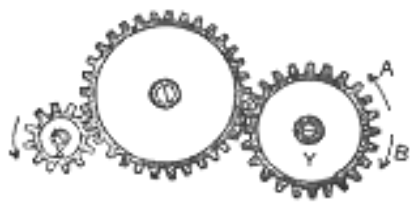

Berdasarkan gambar, testee diminta menentukan arah gerak roda bergigi $Y$ bila roda bergigi $X$ berputar ke arah seperti ditunjukkan oleh panah. Jawaban ke arah A atau B ?

\section{Expression (Tes Ungkapan)}

\section{a. Pengantar}

Tes ini untuk mengetahui (a) perasaan dan pengetahuan tentang bahasa; (b) kemampuan berkomunikasi secara verbal; serta (c) kemam-puan berkomunikasi tetapi lewat tulisan. b. Bentuk Tiap soal terdiri dari 3 kalimat pernyataan yang harus testee pilih 1 pernyataan yang paling baik dan 1 pernyataan yang paling jelek. 
Dengan demikian setiap soal akan ada 2 jawaban.

Contoh soal :

11. a. Kerja keras adalah salah satu syarat mutlak untuk mencapai masyarakat yang lebih adil dan lebih makmur dalam waktu yang sesingkat-singkatnya. Sebab itu masyarakat yang lebih adil dan lebih makmur itu harus dicapai melalui kerja keras.

b. Masyarakat yang lebih adil dan lebih mak-mur hanya dapat dicapai dengan bekerja sekeras-kerasnya, sebab hanya dengan kita bekerja sekeras-kerasnya masyarakat lebih adil dan lebih makmur itu dapat dicapai dalam waktu yang sesingkat-singkatnya.

c. Untuk mencapai masyarakat yang lebih adil dan lebih makmur dalam waktu yang sesingkat-singkatnya bekerja keras adalah syarat mutlak. Karena itu kita harus bekerja keras untuk mencapai masyarakat yang lebih adil dan lebih makmur.

d. Tes bakat multiple lain nya ada :

1. ASVAB (Armed Services Vocational Aptitude Battery) adalah tes yang mengukur kekuatan dan potensi orang dewasa muda untuk sukses dalam pelatihan militer. Tes yang terdiri dari 10 sub tes:

1) Arithmatic Reasoning

2) Numerical Operations

3) Paragraph Comprehension

4) Word Knowledge

5) Coding Speed

6) General Science

7) Mathematics Knowledge

8) Electronics Information

9) Mechanical Comprehension

10) Authomotive and Shop Information

\section{SAT (Scholastic Aptitude Test)}


SAT (Scholastic Aptitude Test) adalah ujian standardisasi yang diciptakan oleh College Board. Tes yang digunakan jika seseorang ingin mendaftar ke universitas di Amerika untuk jenjang kuliah S1. Selain Amerika, tes SAT juga berlaku di Inggris, Singapura,

Finlandia dan Australia. Tes

ini terdiri dari dua, yaitu: a)

Verbal,meliputi:

b) Antonyms

c) Analogies

d) Sentences Completions

e) Reading Comprehension

b) Mathematics, meliputi:

a) Reguler Mathematics

b) Quantitative Comparisons

\section{Special Aptitude Test (Tes bakat Tunggal)}

Special Aptitude Test adalah tes bakat yang terdiri dari satu jenis tes. Tes bakat tunggal pada umumnya mengungkap kemampuan khusus yang dimiliki seseorang, terfokus pada satu bakat saja. Tes yang termasuk dalam tes bakat tunggal antara lain : 1 . Tes Kraepelin

\section{a. Pengantar}

Nama tes ini diambil dari nama penyusun tes ini yaitu Emilie Kraepelin pada tahun 1856 - 1926. Tes ini dibuat dengan maksud untuk mengetahui kecepatan kerja, ketelitian kerja, keajegan kerja dan ketahanan kerja. Padahal di awal penyusunannya, tes ini dimaksudkan untuk menentukan apakah seseorang tergolong normal atau tidak normal, juga untuk mendiagnosa gangguan otak, misal : alzheimer.

b. Bentuk 
Tes ini berbentuk dobel kuarto yang disusun memanjang.

Tes ini terdiri dari deretan angka-angka antara 0 sampai 9 yang ditata memanjang penuh dalam dobel kuarto sebanyak 45 lajur. Deretan angka ini ada dalam 2 lembar kertas ukuran kuarto (dobel kuarto) memanjang. Ada 3 bagian dalam tes ini :

1. Halaman depan, separo kertas tes sebelah kanan, berisi identitas testee, dan contoh deret angka yang nanti akan dikerjakan. Contoh deret angka di halaman depan dimaksudkan untuk latihan cara mengerjakan sebelum tes dimulai.

2. Halaman depan, sebelah kiri, merupakan halaman untuk menggambarkan grafik aspek kerja (kecepa-tan kerja, ketelitian kerja, keajegan kerja dan ke-tahanan kerja) hasil tes.

3. Halaman belakang, merupakan halaman soal. Hala-man ini berisi deretan angka penuh (dobel kuarto) memanjang yang harus dikerjakan testee.

Pada pelaksanaannya, testee diminta menjumlahkan 2 angka yang berdekatan, dari angka paling bawah ke atas. yang ada dalam satu deret tanpa ada angka yang terlewatkan untuk dijumlah. Contoh soal

2. Tes Kreativitas

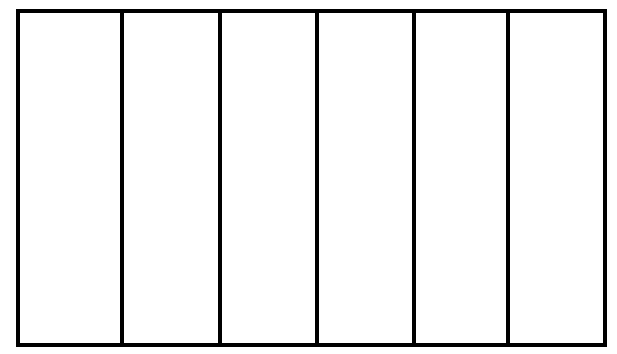

a. Pengantar

Tes kreativitas biasanya digunakan untuk mengu-kur kemampuan berpikir divergen, yaitu kemampuan seseorang untuk menemukan 
berbagai alternatif jawaban (baik dari segi kuantitas, kualitas atau relevansi jawaban) bila mengahadapi suatu persoalan atau masalah. Tes kreativitas yang akan dibahas di sini adalah :

1. Tes Kreativitas Figural

Kreativitas di sini menggambarkan kemampuan seseorang membuat kombinasi baru berdasarkan unsur-unsur yang dihadapi. Aspekaspek kreativitas yang diungkap pada tes kreativitas Figural ada 4 :

a. Kelancaran : kemampuan memberikan ide atau gagasan dengan cepat. Jadi, lebih menekankan jumlah/kuantitas gagasan yang muncul.

b. Kelenturan (fleksibilitas) : kemampuan memberi variasi ide/gagasan yang bebas dari perseverasi.

c. Originalitas : kemampuan memunculkan ide atau gagasan yang bisa dikatakan langka atau unik dibanding gagasan-gagasan yang sudah ada sebelumnya.

d. Elaborasi : kemampuan menggabungkan atau membuat kombinasi baru pada unsur-unsur yang ada. Makin banyar unsur yang digabungkan biasanya dianggap makin original pemikiran seseorang.

\section{Tes Kreativitas Verbal}

Unsur yang akan diukur dalam tes kreativitas verbal adalah :

a. Permulaan kata : untuk mengetahui "kelancaran kata”, yaitu kemampuan seseorang menemukan susunan kata yang sesuai persyaratan.

b. Menyusun kata : mengukur "kelancaran kata" . Unsur b. ini sama dengan poin a. permulaan kata di atas, tetapi ditambah ketrampilan reorganisasi perseptual. 
c. Membuat kalimat dengan 3 kata : mengukur "kelancaran dalam ungkapan", yaitu kemampuan seseorang didalam membuat susunan kalimat sesuai dengan persyaratan yang telah ditentukan.

d. Sifat-sifat yang sama : unsur ini merupakan gam-baran "kelancaran dalam memunculkan gagasan" sesuai dengan persyaratan yang telah ditentukan dengan waktu yang terbatas.

e. Macam-macam penggunaan : unsur ini menggam-barkan 2 hal yaitu "fleksibilitas dalam pemikiran" (melepaskan diri dari berpikir seperti biasanya), dan "originalitas dalam pemikiran" (memberikan jawaban yang tergolong langka, jarang dimunculkan oleh banyak orang).

f. Apa akibatnya : mengukur kemampuan imajinasi dan menguraikan gagasan/ide-ide dalam pikirannya.

b. Bentuk

1. Tes Kreativitas Figural :

Tes ini terdiri dari lingkaran-lingkaran sebanyak satu halaman bolakbalik. Testee diminta membuat gambar sebanyak mungkin. Gambarnya dibuat dari lingkaran-lingkaran yang ada di lembar jawaban, dan lingkaran soal harus merupakan bagian utama gambar yang dibuat.

Testee juga diminta membuat gambar yang mungkin tidak akan terpikirkan oleh orang lain, dan memberi nama gambar yang sudah dibuat.

Contoh soal :
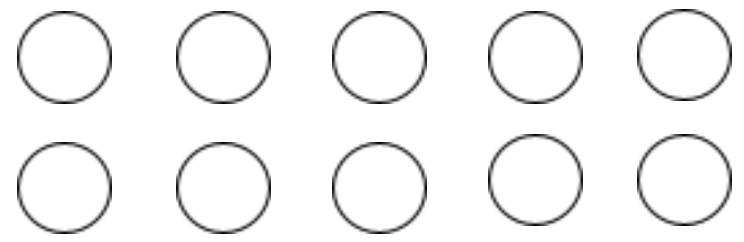

2. Tes Krativitas Verbal : 
a. pada sub tes Permulaan kata, testee diminta menyusun sebanyak mungkin kata dari huruf yang ada. Contoh soal :

\section{1. $\mathrm{Ti}$}

b. pada subtes Menyusun kata

pada sub tes Menyusun Kata, testee diminta menyusun kata-kata sebanyak banyaknya dari kata yang ada. Contoh soal :

1. Keajaiban

c. Pada subtes Membentuk kalimat 3 kata, testee diminta menyusun kalimat dari 3 huruf yang ada di setiap soal, dengan susunan sesuai keinginan testee. Contoh soal:

1. $a-m-p$

d. Pada subtes Sifat-sifat yang sama, testee diminta menyebutkan obyek-obyek yang memiliki 2 sifat yang sama seperti dalam soal. Contot soal :

1. Bulat dan keras

e. Pada subtes Macam-macam penggunaan, testee diminta menyebutkan penggunaan yang tidak biasanya dari obyek atau benda sehari-hari seperti yang ada di soal. Contoh soal :

1. Surat kabar

f. Pada subtes Apa akibatnya, testee diminta me-nyebutkan hal-hal apa yang kemungkinan akan terjadi seperti yang ada di soal. Contoh soal :

1. Apa akibatnya, jika setiap orang dapat me-ngetahui pikiran orang lain?

3. Tes Pauli

a. Pengantar

Tes Pauli merupakan pengembangan dari bentuk test Kraepelin. Tes ini digunakan untuk melihat dan mengetahui hasil kerja yang dipengaruhi oleh beberapa faktor seperti ketelitian, kecepatan, ketekunan dan juga daya tahan. 
Baik Tes Pauli maupun Tes Kraepelin digunakan untuk mengukur beberapa elemen seperti produk-tivitas kerja, keuletan kerja, konsistensi, daya tahan kerja dan sikap terhadap tekanan, ketelitian dan kecepatan dalam mengerjakan suatu hal, kemampuan untuk mengendali-kan emosi, sikap kerja, dan kemampuan untuk menyesuaikan diri dengan berbagai hal di sekitarnya. b. Bentuk Bentuk soal tes Pauli sama dengan tes Kraepelin, yaitu tes nya terdiri dari deretan angka-angka antara 0 sampai 9 yang ditata memanjang penuh satu halaman bolak balik. Ukuran kertas soal tes Pauli lebih besar. Pada tes pauli testee diminta menjumlahkan 2 angka yang berdekatan dari atas ke bawah, berbeda dengan tes Kraepelin yang dikerjakan dari bawah ke atas.

\section{Tes Sensory \\ a. Pengantar}

Tes sensory ini tes yang mengungkap kemampuan indera, misal :

a. Tes ketajaman penglihatan

Tes ketajaman penglihatan/visual memakai alat yang dinamakan kartu Snellen. Kartu Snellen berisi barisan huruf dimulai huruf yang besar bentuknya menurun sampai pada yang terkecil dengan ukuran sudut visual

b. Tes pendengaran

Alat tes untuk mengetes ketajaman pendengaran disebut audiometer, yaitu dengan cara subyek memakai handphone yang dihubungkan dengan sumber suara.

5. Tes Artistik

a. Pengantar

Tes artistik ini adalah tes yang mengungkap bakat seni, misal: tes gambar dan tes musik. 


\section{Tes Klerikal}

\section{a. Pengantar}

Tes klerikal digunakan untuk mengukur keakuratan (ketepatan, ketelitian) dan kecepatan respon dalam tugas-tugas pekerjaan yang membutuhkan persepsi sederhana.

Hasil tes ini untuk prediksi kemampuan mengerjakan hal-hal penting rutin dalam administrasi, seperti mengatur arsip.

\section{Motor dexterity}

a. Pengantar

Tes ini merupakan tes ketangkasan / ketrampilan motorik.

\section{RINGKASAN}

Tes Bakat dan Minat mulai berkembang setelah muncul ketertarikan untuk mengetahui Bakat Khusus. Mulai muncul usaha penyusunan tes-tes secara terpisah untuk mengukur potensi bakat. Ada beberapa macam Tes Bakat, baik yang multiple maupun yang tunggal.

Tes Bakat adalah tes yang dirancang untuk mengukur kecenderungan kemampuan potensial yang dimiliki seseorang dalam satu jenis aktivitas khusus.

Tes bakat kelompok, atau multiple battery test, adalah tes yang dirancang untuk mengukur kemampuan siswa dan siswa sekolah menengah dan atas untuk belajar atau berhasil di bidang-bidang tertentu. Beberapa tes yang termasuk ini adalah : DAT. GATB, FACT, ASVAB, SAT.

DAT (Differential Aptitude Tests), terdiri dari : (1) Verbal Reasoning; (2) Tes Berhitung (numerical ability); (3) Tes Penalaran (abstract 
reasoning); (4) Tes Pola (Space Relation); (5) Tes Pengertian Mekanik (Mechanical Reasoning); (6) Tes Cepat dan Teliti (Clerical

Speed and Accuracy); (7\&8) Language Usage : I. Spelling ; II. Sentences .

GATB (General Aptitude Tests Battery), terdiri dari : 12 sub tes yang digunakan untuk mengukur 9 kemampuan dasar atau bakat, yaitu (1) General Learning Ability; (2) Verbal Aptitude; (3) Numerical Aptitude; 4. Spacial/Three Dimentional Space (Tes Ruang Bidang); 5. Form Perception (Tes mempersamakan Perkakas); 6. Clerical Perception; 7. Motor Coordination; 8. Finger Dexterity (Tes Kecepatan Jemari); 9. Manual Dexterity.

FACT (Flanagan Aptitude Classification Tests), terdiri dari : (1) Tes Inspection; (2) Coding (Tes Kode dan Ingatan); (3) Memory; (4)

Precision; (5) Assembly (Merakit Obyek); (6) Scales (Tes Skala dan Grafik); (7) Coordination; (8) Judgment and Comprehension (Tes Pemahaman); (9) Arithmatic; (10) Patterns (Tes Mengutip); (11) Components (Tes Komponen); (12) Tables (Tes Tabel); Mechanics; (14) Expression (Tes Ungkapan)

Tes bakat tunggal adalah tes bakat yang terdiri dari satu jenis tes. Tes bakat tunggal pada umumnya mengungkap kemampuan khusus yang dimiliki seseorang, seperti : tes Kraepelin, Tes Kreativitas, dsb.

\section{LATIHAN SOAL}

1. Jelaskan definisi tes bakat

2. Jelaskan ada berapa macam tes bakat multiple

3. Jelaskan apa yang dimaksud dengan tes bakat tunggal! Bericontoh tes yang termasuk tes bakat tunggal 


\section{E. TUGAS}

Buat kelompok yang terdiri dari 3-4 orang. Tugasnya adalah (a) mempelajari salah satu tes bakat, (2) menjelaskan salah satu tes bakat yang dipelajari, (3) mempraktekkan administrasi tes bakat tersebut

\section{F. REFERENSI}

Alsa, A, dkk. (2004). Informasi Tes. LPKM Fakultas Psikologi Universitas Gadjah Mada.Divisi Ritel.Jogjakarta

Bennet, G.K., Seashore, H.G., Wesman, A.G., 1952. Differential

Aptitude Test Manual. Second Edition. New York, The Psychological Corporation.

Cohen, R.J., Swerdlik, M.E. 2010. Psychological Testing and Assessment: An Introduction to Test And Measurement (7th Ed.). New York: McGraw-Hill.

Febrianty, Catherine. 2015. Karakteristik Psikometri Tes Kraepelin. Sumatera : Universitas Sumatera Utara.

Flanagan, J.C.,1953. FACT. Examiner Manual. Chicago,Science Research Associates. Inc.

HIMPSI, 2000. Materi Penyegaran Psikodiagnostik.

Odell, Ch. E, 1968. Manual for The GATB. Washington, U.S. Dept of Labor

Setiawati, F.A, dkk. (2018). Evaluasi Karakteristik Psikometrik Tes Bakat Differensial Dengan Teori Klasik . Humanitas, Vol.15, No.1, Februari 2018, Hal. 46 - 61.

Wang, Lin (1993). The Differential Aptitude Test : A Review and 
Critique. Paper. Presented at the Annual Meeting of the Southwest Educational Research Association (Austin, TX, January 28-30, 1993).

"General Aptitude Test Battery (GATB) - Career Assessment iResearchNet". Career Research. 2015-03-23.

Retrieved 2017-03-04.

......... , 2011. Petunjuk Penggunaan TKF. Tes Kreativitas Figural. Manual Tes Kreativitas Figural. LPSP3 UI

......... , 2011. Petunjuk Penggunaan TKV. Tes Kreativitas Verbal. Manual Tes Kreativitas Verbal. LPSP3 UI

BAB V APLIKASI TES MINAT DAN BAKAT

\section{Kemampuan Akhir Yang Direncanakan :}

1. Mahasiswa mampu menerapkan tes minat dibidang pendidikan, industri, penelitian, pekerjaan

2. Mahasiswa mampu menerapkan tes bakat dibidang pendidikan, industri, penelitian, pekerjaan

\section{A. PEngantar}

Seperti diketahui bahwa psikologi adalah ilmu yang mempelajari perilaku manusia, maka psikodiagnostik dibutuhkan untuk mengukur potensi yang dimiliki manusia di setting dimana manusia berada. Di bidang klinis, misalnya, psikodiagnostik dibutuhkan untuk membantu mendeteksi apakah seorrang klien mengalami gangguan psikis, sekaligus mengetahui potensi kekuatan atau kemampuan yang ada 
pada diri klien. Potensi ini akan membantu terapis menentukan treatment apa yang bisa diberikan pada klien.

Di bidang lain seperti bidang pendidikan, psikodiagnostik dimanfaatkan untuk membantu menentukan jurusan pendidikan yang tepat bagi siswa). Di bidang industri, psikodiagnostik digunakan untuk membantu mengukur potensi calon pekerja dalam proses seleksi, apakah sesuai dengan bidang kerja yang ada di perusahaan). Selain itu juga di research setting (pengembangan ilmu dan pengmbangan teknik serta metode diagnostik).

Sebagai bagian dari psikodiagnostik, tes bakat dan tes minat juga digunakan di berbagai bidang. Tes Minat bakat banyak dilakukan yang bertujuan membantu individu (peserta didik) menyesuaikan jurusan atau menentukan ekstra kurikuler apa dalam pendidikan sehingga bakat dan potensinya dapat diaktualkan secara optimal. Tes DAT cocok untuk administrasi kelompok dan terutama digunakan dalam pendidikan dan konseling kejuruan, meskipun dapat juga digunakan dalam pemilihan dan konseling karyawan.

Selanjutnya pembahasan aplikasi tes minat bakat di berbagai bidang akan dijelaskan di bawah.

\section{B. APLIKASI TES MINAT}

Melihat fungsinya, kita bisa mengetahui bahwa tes minat bisa digunakan di 3 bidang terapan yaitu :

1. Perusahaan :

Perusahaan bisa memnafaatkan tes minat untuk tujuan-tujuan seperti :

a. Konseling Karier : 
Tes minat (dan dibarengi dengan tes bakat) akan sangat membantu tim rekrutmen perusahaan saat harus menempatkan karyawan agar sesuai dengan ke-tertarikannya pada suatu bidang pekerjaan. Contohnya, selain untuk keperluan rekruitmen, tes Kraepelin sering juga dimafaatkan untuk kepentingan promosi dan mutasi dalam bidang kerja dan jabatan.

b. Konseling Pekerjaan :

Konseling ini diberikan pada karyawan yang telah bekerja di suatu perusahaan. Penggunaan tes minat di sini sebagai alat untuk mengetahui minat karyawan yang sebenarnya, apalagi bila di awal bekerja tidak dilakukan pengukuran minat.

Fungsi konseling ini :

(1) Konselor mengindentifikasi apakah permasalahan yang dialami karyawan di bidang yang digelutinya itu berkaitan dengan sesuai atau tidak sesuainya pekerjaan dengan minat karyawan yang sebenarnya.

(2) Konselor dapat mengecek konsistensi antara tugas yang telah (terlanjur) dijalani karyawan dengan pilihan pekerjaan yang sebenarnya disukai karyawan.

(3) Konselor dapat membantu karyawan yang karirnya terhambat karena ketidak cocokan yang muncul pada poin 2

(4) Konselor membantu karyawan yang mulai mengalami kebosanan pada pekerjaannya.

(5) Untuk peningkatan efisiensi perusahaan dan kepuasan kerja.

c. Placement :

Alat tes RMIB (Rothwell Miller Interest Blank) juga bisa di-gunakan perusahaan didalam menentukan posisi pekerjaan apa yang sesuai untuk seorang karyawan, apakah layak untuk menduduki jabatan manajer produksi, dan sebagainya. 


\section{Pendidikan :}

Sekolah bisa memanfaatkan tes minat yang ada untuk membantu kegiatan-kegiatan seperti :

a. Penjurusan Siswa, yaitu penempatan siswa pada jurusan atau program pendidikan yang tersedia di sekolah :

Penggunaan tes minat (dan dilengkapi dengan tes kemampuan lainnya) akan sangat membantu seorang siswa saat harus memilih jurusan apa yang sesuai dengan kemampuan dan minat. Banyak siswa yang tidak mengetahui secara pasti jurusan apa sebenarnya diminati karena banyaknya faktor yang mempengaruhinya.

Penentuan jurusan dipengaruhi oleh faktor internal dan faktor eksternal. Faktor internal berasal dari dalam diri peserta didik, meliputi minat, kemampuan, motivasi, cita-cita, dan perhatian. Oleh karena itu, ada sekolah yang menggunakan pertimbangan bahwa untuk pemilihan jurusan program ditentukan oleh nilai akademik dan minat peserta didik.

Alat tes RMIB banyak digunakan di dunia pendidikan, antara lain untuk tujuan penjurusan di SMA, atau membantu siswa menentukan program studi apa yang bisa dipilih di Perguruan Tinggi, yang sesuai dengan minatnya.

b. Konseling karir:

Tes minat di sekolah salah satunya juga digunakan untuk membantu

(1) Siswa-siswa sekolah, khususnya SMA tahun pertama, untuk menunjukkan bidang-bidang pekerjaan secara umum dan luas, agar siswa mendapatkan pemahaman dan segera mempersempit alternatif (fokus) pada bidang pekerjaan yang jelas. 
(2) Siswa sekolah kejuruan yang merencanakan untuk segera bekerja setelah lulus. Tes minat akan membantu

mengetahui bidang pekerjaan apa yang bisa mereka masuki setelah lulus.

(3) Orang-orang putus sekolahlanjutan yang sedang mencari pekerjaan yang cocok dengan minatnya yang sebenarnya.

c. Perencanaan bacaan pendidikan :

Dalam proses pembelajaran di sekolah :

(1) Dalam sistem pendidikan klasikal, tes minat digunakan untuk mengetahui materi bacaan yang tepat bagi siswa agar prestasi mereka juga meningkat. Juga akan membantu peserta didik memperoleh informasi yang luas tentang aktivitas yang sesuai minatnya.

(2) Penentuan buku bacaan bisa dibantu dari hasil pemberian tes minat pada siswa. Untuk skala yang lebih besar, digunakan untuk perencanaan pemilihan \& penerbitan buku-buku bacaan yang disukai oleh siswa pada suatu daerah.

\section{Penelitian :}

Penelitian berkaitan dengan pengembangan ilmu dilakukan lewat penelitian, misal :

Mudhar, dkk. (2020), Penelitian ini dilakukan untuk mengetahui tren minat siswa SMA di Surabaya, Jawa Timur, Indonesia sebanyak 981 yang terdiri dari 488 pria dan 493 wanita. Instrumen yang digunakan adalah skala minat karir yang disusun berdasarkan teori Holland dengan enam domain RIASEC (Realistis, Investigatif, Artistik, Sosial, Enterprising, dan Konvensional). Hasilnya menunjukkan bahwa 
Bidang karir yang diminati oleh siswa sekolah menengah adalah bidang konvensional yang mencapai $42,30 \%$, sedangkan bidang yang kurang diinginkan adalah bidang inovatif yang hanya 3,98\%. Ada perbedaan minat karier antara pria dan wanita. Pria lebih suka bidang realistis, artistik dan enterprising, sedangkan perempuan lebih suka bidang sosial dan konvensional.

Kabinani, I.M., Rostianingsih S., dan Dewi L.P., mencoba membuat aplikasi psikotes yang bertujuan untuk membantu para fresh graduate mengetahui posisi pekerjaan yang tepat saat bekerja setelah lulus kuliah. Tes minat yang dibuatkan aplikasinya adalah tes Holland (Self Directed Search/SDS)

\section{APLIKASI TES BAKAT}

1. Bidang Pendidikan

Di awal sejarah perkembangannya, penggunaan tes bakat banyak dimanfaatkan untuk membantu perusahaan menentukan apakah seorang calon pekerja memiliki kemampuan seperti yang diharapkan perusahaan di bidang pekerjaan tertentu. Pada perkembangan selanjutnya, kemudian bidang pendidikan juga menggunakan tes bakat untuk keperluan pendidikan seperti untuk mengarahkan siswa pada pendidikan sesuai kemampuannya yang menonjol (Anastasi, 1997).

Bahkan saat ini, sekolah-sekolah menyadari perlunya mengetahui bakat yang dimiliki peserta didik, dan sekolah menyelenggarakan pengukuran bakat siswa dengan menggunakan tes bakat untuk banyak tujuan. Hasil pengukuran bakat siswa bisa menjadi bahan pertimbangan pemilihan penjurusan atau studi lanjut siswa nantinya. Salah satu hal yang menentukan kesuksesan siswa pada setiap bidang studi, atau bahkan di bidang karirnya kelak ditentukan oleh 
bakat yang dimilikinya. Sebagai contoh, siswa yang memiliki bakat atau kemampuan "ruang bidang" yang tinggi akan berprestasi bila masuk di jurusan IPA, dan akan sukses pada studi lanjut di bidang arsitek di perguruan tinggi.

Kelompok tes seperti Tes bakat differensial atau Differential Aptitude Test (DAT) sering dipakai untuk tujuan pendidikan seperti tersebut di atas. Di Indonesia, DAT banyak digunakan di bidang pendidikan, terutama untuk tujuan membantu sekolah didalam proses penelusuran bakat terkait pemilihan program di SMA dan penelusuran karir untuk jenjang pendidikan lanjut.

Penerapan pengukuran potensi bakat seseorang sering dilakukan dengan tujuan :

a. Penjurusan, atau pemilihan program belajar yang ada di SMA

b. Penentuan Program studi di Perguruan tinggi

Seorang calon mahasiswa sering mengalami kesulitan menentukan program studi apa yang cocok dengan bakat nya karena mereka tidak tahu secara pasti potensi bakat apa yang sebenarnya dimilikinya.

HASIL penelitian Indonesia Career Center Network (ICCN) tahun 2017 menunjukkan bahwa sebanyak $87 \%$ mahasiswa di Indonesia mengakui jurusan yang diambil tidak sesuai dengan minatnya. Hal tersebut akan berdampak kepada kemungkinan kesulitan bagi siswa yang bersangkutan untuk menyelesaikan pendidikannya secara tepat waktu atau ketidakmaksimalan hasil studi siswa tersebut.

https://mediaindonesia.com/read/detail/288145-tes-bakat-minat-u ngkap-potensi-dan-pandu-pelajar-pilih-jurusan, diunduh pada $31 \mathrm{Juli}$ 2020

Kesalahan dalam menentukan pilihan pada tahap awal dapat memberikan dampak yang tidak baik kepada calon mahasiswa, terutama pada saat mereka menjalani masa-masa akademik, seperti sulit untuk mengikuti kuliah, malas, tidak fokus, nilai akademik tidak 
maksimal, bahkan tidak sedikit yang akhirnya putus kuliah. Jika hal ini terus terjadi, maka banyak mahasiswa yang menemukan kegagalan pada masa akademiknya. c. Penelusuran karir

Tes bakat bisa membantu siswa SMP mengetahui apakah sebaiknya melanjutkan ke sekolah kejuruan atau sekolah lanjutan atas, sebaiknya nanti memilih program pendidikan lanjut IPA atau IPS atau Bahasa.

Tes bakat juga bisa membantu siswa SMA mengetahui apakah sebaiknya melanjutkan program studi tertentu atau mengambil kursus ketrampilan kerja tertentu.

d. Penentuan ekstrakurikuler.

Upaya untuk pemilihan kegiatan ekstrakurikuler (untuk pengembangan diri siswa) yang harus disediakan sekolah sehingga semua bakat yang dimiliki setiap siswa berkembang optimal .

\section{Bidang pekerjaan / industri}

Tes DAT (Differential Aptitude Tests) cocok untuk administrasi kelompok dan terutama digunakan dalam pendidikan dan konseling kejuruan, meskipun dapat digunakan dalam pemilihan karyawan.

Sejak Perang Dunia I para psikolog mulai membuat tes-tes aptitude yang diperuntukan khusus untuk kebutuhan konseling pekerjaan (vocational counseling). Kelompok tes seperti General Aptitude Test Battery (GATB) menjadi pilihan psikolog untuk keperluan tersebut.

Kelompok tes lain, yaitu FACT (Flanagan Aptitude Classification Tests) dapat meramal kurang lebih 30 pekerjaan berdasarkan penggabungan subtest-subtest FACT, misal : untuk pekerjaan akuntan subtes yang diberikan adalah subtes coding, memory, judgement \& comprehension, arithmatic, dan tables. Seseorang 
dengan skor tinggi pada 5 subtes tersebut akan menjadi akuntan yang berhasil.

\section{Bidang penelitian}

Beberapa penelitian berkaitan dengan pengembangan ilmu dilakukan lewat penelitian, misal :

Afifah (2012), mencoba melakukan pengujian beberapa sub tes pada kelompok tes GATB dengan menggunakan teori modern, karena belum ada pengujian validitas pada item subtes GATB yang menyebabkan item subtes GATB belum memuaskan. Tes dilakukan pada tahun 2009 kepada 3257 orang yang mengikuti proses rekruitmen sebuah perusahaan.

Empat subtes dalam GATB yang mengukur bakat skolastik yang digunakan dalam penelitian, meliputi computation, three dimensional space, vocabulary, dan arithmetic reasoning. Analisis hasil penelitian menggunakan metode CFA (Confirmatory Factor Analysis), dan hasilnya menunjukkan bahwa semua subtes fit (sesuai) mengukur model satu faktor, kecuali subtes three dimensional space serta artihmetic reasoning dianggap perlu dilakukan modifikasi model pengukuran untuk dapat nilai fit. Hasil analisis faktor dua tingkat (Second Order Confirmatory Factor Analysis) menunjukkan terdapat 3 (dari 4) subtes GATB yang signifikan bila digunakan untuk mengukur inteligensi umum, yaitu subtes computation, three dimensional space, dan vocabulary.

Rahman (2014), melakukan penelitian di Bangladesh, menyusun instrumen teacher aptitude test berdasarkan standardized test: GATB, DAT, SATB, TATB, TAT, Wellesley Spelling Scale, Yale Educational Aptitude Test Battery, Multiple Aptitude Test, dan Online Aptitude test. Instrumen nya terdiri dari 259 butir, menjadi 5 subtes (penalaran, subtes verbal, numerikal, bahasa Inggris, dan bahasa 
Bangle). Subyek penelitian adalah 100 orang guru, dan hasil penelitian menunjukkan bahwa $90 \%$ butir memiliki tingkat kesukaran dengan interval 0,40 sampai 0,76 dan $46 \%$ butir, memiliki daya beda yang baik; serta reliabilitas subtes bahasa Bangle, bahasa

Inggris, numerikal, penalaran, dan verbal berturut-turut adalah 0,$701 ; 0,604 ; 0,598 ; 0,724$; dan 0,506.

Setiawati, F.A, dkk. (2018), melakukan penelitian di Indonesia, mengevaluasi karakteriktik psikometrik DAT dengan subyek penelitian di Indonesia dengan harapan terdapat kesesuaian dan ketepatan hasil pengukuran dan dapat dipertanggungjawabkan.

Instrumen peneltian ini adalah instrumen Tes Bakat Diferensial yang diadaptasi dari instrumen yang disusun oleh Bennet, Harold G.

Seashore, \& Alexander G. Wesman pada tahun 1947. Instrumen ini berbentuk multiple choice dan terdiri dari lima subtes (verbal, numerical, penalaran, relasi ruang, mekanik). Subyek penelitian adalah 2118 siswa di Daerah Istimewa Yogyakarta (DIY). Analisis karakteristik psikometrik instrumen dengan menggunakan pendekatan klasik. Karakteristik instrumen yang dianalisis adalah indeks kesukaran soal, indeks daya beda, keberfungsian pengecoh dan koefisien reliabilitas. Data dianalisis dengan bantuan program Microcat ITEMAN 3.0. Hasil analisis penelitian menunjukkan indeks kesulitan butir butir instrumen ini bervariasi. Sebagian besar indeks daya beda tergolong baik dan beberapa butir tergolong rendah atau perlu perbaikan. Butir-butir pada subtes berpikir abstrak memiliki banyak pengecoh yang tergolong tidak berfungsi efektif, dan semua subtes DAT tergolong reliabel. 


\section{RINGKASAN}

Tes bakat dan tes minat juga digunakan di berbagai bidang. Tes DAT, misal, digunakan dalam pendidikan dan konseling kejuruan, dapat juga digunakan dalam pemilihan dan konseling karyawan. Bidang riset, menggunakan tes bakat minat untuk tujuan pengambangan alat tes.

Hasil tes minat bisa digunakan di 3 bidang terapan yaitu :

1. Perusahaan :

a. Konseling Karier;

b. Konseling Pekerjaan;

c. Placement 2. Pendidikan :

a. Penjurusan Siswa (penempatan siswa pada jurusan atau program pendidikan yang tersedia di sekolah);

b. Konseling karir;

c. Perencanaan bacaan pendidikan

3. Penelitian :

Mudhar, dkk. (2020), mengetahui tren minat siswa SMA di Surabaya, Jawa Timur, Indonesia dengan menggunakan skala minat karir yang disusun berdasarkan teori Holland.

Tes Bakat bisa diaplikasikan di 3 (tiga) bidang :

1. Bidang Pendidikan. Penerapan pengukuran potensi bakat siswa sering dilakukan dengan tujuan :

a. Penjurusan, atau pemilihan program belajar di SMA;

b. Penentuan Program studi di Perguruan tinggi;

c. Penelusuran karir; d. Penentuan ekstrakurikuler yang disediakan sekolah

2. Bidang pekerjaan / industri :

a. Tes DAT (Differential Aptitude Tests) dapat digunakan dalam pemilihan karyawan. ; 
b. General Aptitude Test Battery (GATB) diperuntukan khusus untuk kebutuhan konseling pekerjaan (vocational counseling) yang juga dapat melengkapi tes-tes inteligensi umum.;

c. FACT (Flanagan Aptitude Classification Tests) dapat memprediksi kurang lebih 30 pekerjaan berdasarkan penggabungan subtest-subtest FACT.

3. Bidang penelitian, berkaitan dengan pengembangan ilmu dilakukan lewat penelitian, misal :

a. Afifah (2012), menguji validitas konstruk dari GATB, sebagai alat tes yang telah lama digunakan dan menjadi salah satu alat tes yang tertua.

b. Rahman (2014), melakukan penelitian di Bangladesh, menyusun instrumen teacher aptitude test berdasarkan standardized test: GATB, DAT, SATB, TATB, TAT, Wellesley Spelling Scale, Yale Educational Aptitude Test Battery, Multiple Aptitude Test, dan Online Aptitude test.

c. Setiawati, F.A, dkk. (2018), melakukan penelitian di Indonesia, mengevaluasi karakteriktik psikometrik DAT dengan subyek penelitian di Indonesia.

\section{E. LATIHAN SOAL}

1. Jelaskan bagaimana aplikasi tes Minat dan Bakat di bidangpendidikan

2. Jelaskan bagaimana aplikasi tes Minat dan Bakat di bidangpekerjaan

3. Jelaskan bagaimana aplikasi tes Minat dan Bakat di bidangpenelitian

\section{F. TUGAS :}


1. Reviu jurnal penelitian yang temanya aplikasi tes minat atau tesbakat di bidang apa saja.

2. Mengaplikasikan secara langsung tes minat, atau tes bakat, ataugabungan tes minat dan tes bakat

\section{G. REFERENSI}

Afifah (2012). Uji Validitas Konstruk General Aptitude Test Battery (GATB) dengan Metode Confirmatory Factor Analysis (CFA). Jurnal Pengukuran Psikologi dan Pendidikan Indonesia, Vol I, No 1, Januari 2012.

Anastasi, Anne \& Susana Urbina, 1997. Tes Psikologi. Psychological Testing. Edisi ketujuh. Terjemahan Robertus Hariono S.I. 2007.

Penerbit PT. Indeks, Jakarta.

Mudhar, dkk. (2020). Career interest data trends in era information technology of high school students at Surabaya, Indonesia.

Published by Elsevier Inc.

(https://doi.org/10.1016/j.dib.2020.105480)

Neukrug, E.S., Fawcett, R.C. 2010. Essentials of Testing and Assessment: A Practical Guide for Counselors, Social Workers and Psychologist (2nd Ed.). Kanada: Brook/Cole Cengange Learning.

Rahman, A. (2014). Developing Teaching Aptitude Test: A Perspective Of Bangladesh. Green University Review of Social Sciences, 1 (1), 75-89.

Setiawati, F.A, dkk. (2018). Evaluasi Karakteristik Psikometrik Tes Bakat Differensial Dengan Teori Klasik . Humanitas, Vol.15, No.1, Februari 2018, Hal. $46-61$. 
Kabinani,I.M., Rostianingsih, S., dan Dewi, L.P. Perancangan Dan Pembuatan Aplikasi Psikotes Eksplorasi Karir Dan Tes Minat Jabatan Pada Pusat Karir Universitas Kristen Petra. Program Studi Teknik Informatika Fakultas Teknologi Industri Universitas Kristen Petra (https://media.neliti.com/media/publications/104085-ID-perancang an-dan-pembuatan-aplikasi-psiko.pdf)

\section{DAFTAR PUSTAKA}

Afifah, 2012. Uji Validitas Konstruk General Aptitude Test Battery (GATB) dengan Metode Confirmatory Factor Analysis (CFA). Jurnal Pengukuran Psikologi dan Pendidikan Indonesia, Vol I, No 1, Januari 2012.

Alsa, A, dkk. 2004. Informasi Tes. LPKM Fakultas Psikologi Universitas Gadjah Mada.Divisi Ritel. Jogjakarta

Anastasi, Anne \& Susana Urbina, 1997. Tes Psikologi. Psychological Testing. Edisi ketujuh.Terjemahan Robertus Hariono S.I. 2007. Penerbit PT. Indeks, Jakarta.

Bennet, G.K., Seashore, H.G., Wesman, A.G., 1952. Differential Aptitude Test Manual. Second Edition. New York, The Psychological Corporation. 
Cohen, R.J., Swerdlik, M.E. 2010. Psychological Testing and Assessment: An Introduction to Test And Measurement (7th Ed.). New York: McGraw-Hill.

Febrianty, Catherine. 2015. Karakteristik Psikometri Tes Kraepelin. Sumatera : Universitas Sumatera Utara.

Flanagan, J.C.,1953. FACT. Examiner Manual. Chicago,Science Research Associates. Inc.

HIMPSI, 2000. Materi Penyegaran Psikodiagnostik.

Holland, J. L. 1997. Making vocational choices: A theory of vocational personalities and work environments (3rd ed.). Psychological Assessment Resources.

Kifudyartanta. 2009. Pengantar psikodiagnostik. Yogyakarta: Pustaka Pelajar.

Marnat, G.G., 2009. Handbook of Psychological Assessment. Fifth Edition. Alih bahasa : Drs. Helly P.P, MA. \& Dra. Sri

Mulyantini S., 2010. Cetakan I. Pustaka Pelajar, Yogyakarta.

Markam, S.S. 1990. Pengantar Psikodiagnostik. Jakarta: Lembaga Pengembangan Sarana Pengukuran Dan Pendidikan Psikologi Fakultas Psikologi Universitas Indonesia

Marnat, G.G. 2009. Handbook of Psychological Assessment. Fifth Edition. Alih bahasa : Drs. Helly P.P, MA. \& Dra. Sri Mulyantini S., 2010. Cetakan I. Pustaka Pelajar, Yogyakarta.

Mudhar, dkk. 2020. Career interest data trends in era information technology of high school students at Surabaya, Indonesia. Published by Elsevier Inc. 
(https://doi.org/10.1016/j.dib.2020.105480)

Neukrug, E.S., Fawcett, R.C. 2010. Essentials of Testing and Assessment: A Practical Guide for Counselors, Social Workers and Psychologist (2nd Ed.). Kanada: Brook/Cole Cengange Learning.

Odell, Ch. E, 1968. Manual for The GATB. Washington, U.S. Dept of Labor

Rahman, A. 2014. Developing Teaching Aptitude Test: A Perspective Of Bangladesh. Green University Review of Social Sciences, 1 (1), 75-89.

Rothwell \& Miller, K. (....). Petunjuk Penggunan Tes: Inventarisasi Minat The Rothwell-Miller Interest Blank (Manual Test RMIB). Diedit dan disusun kembali : Staf LPSP3 Fakultas Psikologi UI. Penerbit LPSP3 Fakultas Psikologi Universitas Indonesia.

Setiawati, F.A, dkk. 2018. Evaluasi Karakteristik Psikometrik Tes Bakat Differensial Dengan Teori Klasik . Humanitas, Vol.15, No.1, Februari 2018, Hal. $46-61$.

Sugiyanto,dkk. 1984. Informasi Tes. Edisi Kedua. Unit Pengembangan Alat Tes Psikodiagnostik Fakultas Psikologi UGM, Yogyakarta.

Suryabrata, S 2005. Pembimbing ke Psikodiagnostika.

Terlaak, J.J.F, 1996. Psychodiagnostics : Content and Method. Utrecht : Netherland. (diunduh pada tgl 14 -9-2020 http://sayyidasopandi-fpsi12.web.unair.ac.id/artikel detail-8 5848-Psikodiagnostik\%20I-Definisi\%20dan\%20Fungsi\%20Psi kodiagnostik.html) 
Wang, Lin, 1993. The Differential Aptitude Test : A Review and Critique. Paper. Presented at the Annual Meeting of the Southwest Educational Research Association (Austin,TX, January 28-30, 1993).

"General Aptitude Test Battery (GATB) - Career Assessment iResearchNet". Career Research.

2015-03-23.

Retrieved 2017-03-04.

......... , 2011. Petunjuk Penggunaan TKF. Tes Kreativitas Figural. Manual Tes Kreativitas Figural. LPSP3 UI

, 2011. Petunjuk Penggunaan TKV. Tes Kreativitas Verbal. Manual Tes Kreativitas Verbal. LPSP3 UI

BIODATA PENULIS

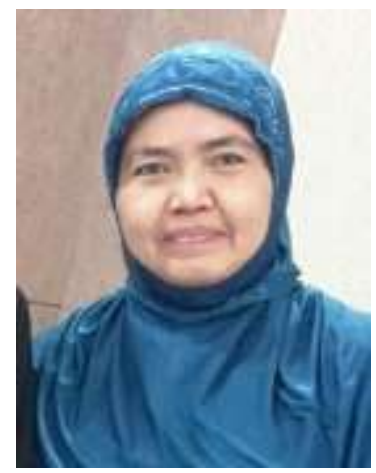

Dra. Dwi Nastiti,M.Si. Psikolog, lahir di Mojokerto,19 Oktober 1963. Pendidikan tinggi S-1 ditempuh di Universitas Surabaya, lulus September 1987, sedangkan S-2 ditempuh di Universitas 17 Agustus 1945 di Surabaya, lulus Januari 2008. Sejak tahun 1988 penulis telah berkecimpung di dunia pendidikan, terutama di perguruan tinggi sebagai dosen psikologi. Di tahun 1988 2008 menjadi dosen tetap di Fakultas Psikologi Universitas Putra Bangsa Surabaya, dan sejak tahun 2010 - 
sekarang menjadi dosen tetap di Fakultas Psikologi Universitas Muhammadiyah Sidoarjo dengan jabatan fungsional terakhir Lektor Kepala. Penulis telah membuat materi-materi kuliah sejak tahun 1988 terdorong oleh terbatasnya literatur psikologi dalam bahasa Indonesia sesuai dengan mata kuliah yang diampu, hanya saja saat itu masih dalam bentuk diktat, dan penyusunan materi perkuliahan masih terus dilakukan penulis sampai saat ini. Alamat e-mail penulis :dwinastiti@umsida.ac.id

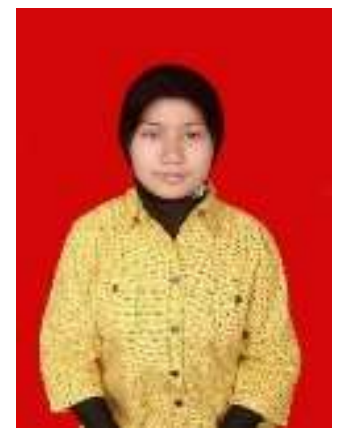

Nurfi Laili, M.Psi., Psikolog lahir di Surabaya, 28 April 1989. Penulis menamatkan studi S1 Psikologi (2012) dan Magister Psikologi Profesinya (2015) di Fakultas Psikologi Universitas Airlangga Surabaya. Kajian penelitian dan studi yang digelutinya sejak jenjang sarjana adalah tentang dunia psikologi pendidikan dan perkembangan pada anak cerdas istimewa dan remaja gifted dan juga mengenai self regulated learning dalam proses belajar mengajar. Penulis aktif melaksanakan layanan asesmen psikologi serta saat ini bertugas sebagai ketua di Pusat Pelayanan Psikologi Terapan Umsida (P3TU) Berkorespondensi dengan penulis dapat melalui nurfilaili@umsida.ac.id 
ISEN $978-623$ 6533742 (FDF:

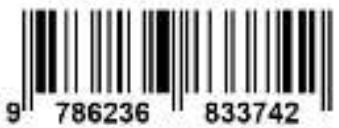

